\title{
HOW THE INCOME TAX TREATMENT OF SAVING AND SOCIAL SECURITY BENEFITS MAY AFFECT BOOMERS' RETIREMENT INCOMES
}

\author{
Barbara A. Butrica, Karen E. Smith, and Eric J. Toder*
}

CRR WP 2008-3

Released: February 2008

Draft Submitted: January 2008

\author{
Center for Retirement Research at Boston College \\ Hovey House \\ 140 Commonwealth Avenue \\ Chestnut Hill, MA 02467
}

Tel: 617-552-1762 Fax: 617-552-0191

*Dr. Barbara A. Butrica is a senior research associate at the Urban Institute. Karen E. Smith is also a senior research associate at the Urban Institute. Eric Toder performs and supervises research on tax policy and retirement policy at the Urban Institute and Urban-Brookings Tax Policy Center. Readers may direct technical questions to Karen Smith (electronic mail: ksmith@ui.urban.org; telephone: 202-261-5275). The research reported herein was pursuant to a grant from the U.S. Social Security Administration (SSA) funded as part of the Retirement Research Consortium (RRC). The findings and conclusions expressed are solely those of the authors and do not represent the views of SSA, any agency of the Federal Government, the RRC, the Urban Institute, Urban-Brookings Tax Policy Center, or Boston College. The authors gratefully acknowledge Jon Bakija for use of his federal and state income tax calculators without which this paper would not be possible. The authors also gratefully acknowledge the expert research assistance from Katherine Michelmore and Matthew Resseger and helpful advice and comments from Richard Johnson and Sheila Zedlewski.

(C) 2008, by Barbara A. Butrica, Karen E. Smith, and Eric J. Toder. All rights reserved. Short sections of text, not to exceed two paragraphs, may be quoted without explicit permission provided that full credit, including (C) notice, is given to the source. 


\title{
About the Center for Retirement Research
}

The Center for Retirement Research at Boston College, part of a consortium that includes parallel centers at the University of Michigan and the National Bureau of Economic Research, was established in 1998 through a grant from the Social Security Administration. The Center's mission is to produce first-class research and forge a strong link between the academic community and decision makers in the public and private sectors around an issue of critical importance to the nation's future. To achieve this mission, the Center sponsors a wide variety of research projects, transmits new findings to a broad audience, trains new scholars, and broadens access to valuable data sources.

\author{
Center for Retirement Research at Boston College \\ Hovey House \\ 140 Commonwealth Avenue \\ Chestnut Hill, MA 02467 \\ phone: 617-552-1762 fax: 617-552-0191 \\ e-mail: crr@bc.edu \\ www.bc.edu/crr
}

\author{
Affiliated Institutions: \\ American Enterprise Institute \\ The Brookings Institution \\ Center for Strategic and International Studies \\ Massachusetts Institute of Technology \\ Syracuse University \\ Urban Institute
}




\begin{abstract}
Income tax provisions affect the buildup of retirement assets during workers' careers and aftertax income following retirement. This paper uses the Urban Institute’s DYNASIM model to simulate how potential changes in the tax treatment of retirement saving, Social Security benefits, and income from assets outside of retirement accounts may affect boomers' retirement incomes. Results show that changes in the income thresholds for taxing Social Security benefits have the largest impact on middle-income boomers, while changes in contribution limits for retirement saving plans and tax rates on capital gains and dividends have the largest impact on the highest income boomers.
\end{abstract}




\section{Introduction}

Tax policy directly affects the amount of wealth individuals can accumulate during their working years and, for a given amount of wealth, the living standards they can enjoy in retirement. Traditionally, Social Security benefits, tax-favored defined benefit plans and retirement saving accounts, and savings accumulated outside of tax-favored accounts have been viewed as the “three-legged stool” of sources of retirement income. How tax policies evolve in the future will affect retirement income from all three sources. Recent tax changes have affected the second and third sources of retirement income. Tax changes enacted in 2001 and made permanent in 2006 expanded access to and increased the amounts people can contribute to tax-preferred individual retirement accounts and employer-sponsored retirement saving plans. Tax changes enacted in 2003 and extended in 2005 reduced tax rates on capital gains and dividends through the end of 2010, thereby increasing after-tax returns outside of tax-favored retirement saving accounts. Tax provisions affecting the treatment of Social Security benefits have not changed since 1993, but the share of Social Security benefits included in taxable income is continually increasing under current law because the threshold levels for inclusion of benefits in income are not indexed for inflation.

This study uses a micro-simulation model of individuals’ lifetime earnings, pensions, and non-pension assets, both actual and projected, to simulate the effects of potential tax policy changes on the retirement income of boomer cohorts. The simulations take account of the two ways that tax policy can affect retirement-by changing accruals of wealth in the years prior to retiring and by changing the taxation of income following retirement. Changes in the tax treatment of saving, both inside and outside of tax-favored accounts, affect the rate of wealth accumulation prior to retirement and the after-tax income that a given stock of wealth produces 
following retirement. In contrast, taxation of Social Security benefits affects only after-tax income in retirement. The effective tax rate on Social Security benefits does, however, depend on income from other sources and therefore is also affected by policy changes that affect the preretirement buildup of assets.

Previous analyses of the distributional effects of income tax provisions, including tax incentives for retirement, examine how they affect a cross-section of the taxpayer population in a given year. (See, for example, Burman et al. 2006.) While these studies show, for example, how tax law changes benefit people of different incomes in different years, they do not show how they affect wealth accumulation of individuals in the same cohort with different lifetime incomes or different future retirement incomes. In contrast, this study examines how changes in income tax rules that remain in place over a number of years will affect the distribution of after-tax income of boomers at retirement.

The second section of the paper reviews recent changes in the tax treatment of retirement income, taxation of investment income outside of retirement plans, and taxation of Social Security benefits. The third section briefly describes the data and micro-simulation model we use to evaluate the policy options and describes our baseline assumptions about future tax law, the policy simulations, and how we represent them in the model. The fourth section presents results of the simulations. A concluding section discusses possible policy implications.

In general, the results show that changes in the income thresholds for taxing Social Security benefits have the largest impact on middle-income boomers, while changes in the contribution limits for retirement saving plans and tax rates on capital gains and dividends have the largest impact on the highest income boomers. 


\section{BACKGROUND: RECENT TAX LAW CHANGES AND BASELINE ASSUMPTIONS}

This section briefly discusses the historical and current income tax treatment of retirement savings accounts, Social Security benefits, and capital gains and dividends. We then describe how we represent baseline tax policy, which does not strictly follow current law.

\section{1(k) and Other Employer-Sponsored Defined Contribution Plans}

Defined contribution (DC) pension plans, which include 401(k) plans, are now the most common type of retirement benefit. In these plans, employees may contribute to a retirement account in the participant's name, with the contributions generally limited either to a percentage of salary, an annual dollar amount, or both. Employers often supplement employee contributions either with a flat contribution or a matching contribution up to a limit. Both employer and employee contributions are excluded from wages subject to income tax (although employee contributions are subject to payroll tax). Investment income accrues tax-free within the accounts.

Withdrawals from the accounts are included in taxable income. After age 59 1/2, workers may either withdraw funds as lump-sum distributions or purchase annuities, although very few elect the latter (Johnson, Burman, and Kobes 2004). Individuals under age 59 1⁄2 who withdraw funds from their retirement accounts upon termination of employment can continue to defer tax by depositing the proceeds in individual retirement accounts (IRAs). But for any withdrawal before age $59 \frac{1}{2}$ that is not rolled over into an IRA, individuals must pay a 10 percent penalty tax in addition to including the withdrawal in taxable income.

The tax law limits how much employees may contribute to tax-qualified employer-sponsored plans and restricts access to deductible IRAs to taxpayers with incomes below ceiling amounts. The Economic Growth and Tax Relief Reconciliation Act of 2001 (EGTRRA) increased the contribution limits for both individual retirement accounts and employer-sponsored retirement 
saving plans over a period of years, thereby directly raising this source of retirement benefits for plan participants who were constrained by contribution limits. EGTRRA also increased income limits for IRA participation. The Pension Protection Act (PPA) of 2006 made the increased contribution limits permanent and indexed them to changes in the price level. Under the PPA, the amounts that may be contributed to 401(k) plans in 2007 are $\$ 15,500$ for all employees plus an additional \$5,000 for employees ages 50 and over.

Between 1985 and 2006, defined contribution plan assets increased from $\$ 508$ billion to $\$ 4,070$ billion (Investment Company Institute 2007). Participation rates, among firms sponsoring 401(k) plans, increased from 38 percent in 1983 to 70 percent in 2003 (Investment Company Institute 2006). For the most part, however, tax-preferred saving vehicles help relatively high-income and highly educated taxpayers more than low-income and less educated taxpayers. Not only do taxpayers with high income and more education have the highest participation rates, but taxpayers in high tax rate brackets benefit the most from the tax exemption of some of their investment income. But 401(k) plans with employer matching can provide very large increases in after-tax wealth per dollar of saving to lower-income participants who contribute just enough to receive the full employer match.

Using administrative data on employee contributions to employer-sponsored DC pension plans, Kawachi, Smith, and Toder (2005) found that the share of employees who contributed the maximum allowed amounts increased between 1990 and 2003, but that most of this increase was by people who were already in high contributing groups (more educated, high earners). Because fewer than 8 percent of participants contributed the maximum amount in 2003, the authors concluded that increases in the maximum allowable contribution would have little effect on retirement savings for most workers. 


\section{Social Security Benefits}

Prior to the 1983 amendments to Social Security, Social Security benefits were exempt from income taxation, even though half of payroll tax contributions (the employer portion) came from pre-tax income and the actuarial value of benefits far exceeded contributions.

The 1983 amendments included up to 50 percent of Social Security benefits in taxable income for taxpayers whose adjusted gross income (AGI) plus one-half of their Social Security benefits and any tax-exempt interest income (“combined income”) exceeded \$25,000 for single tax filers and \$32,000 for joint tax filers. The tax increases in the Omnibus Budget Reconciliation Act of 1993 (OBRA-93) included up to 85 percent of benefits in taxable income for taxpayers whose combined income exceeded $\$ 34,000$ for single tax filers and $\$ 44,000$ for joint tax filers. The 85 percent figure was chosen because it was estimated that employee payroll taxes (the portion of contributions from after-tax income) represented at most 15 percent of Social Security benefits.

One issue regarding these thresholds is that they have remained constant over time- - even as wages and Social Security benefits increase. Only 39 percent of beneficiaries paid taxes on their Social Security benefits in 2000 (Committee On Ways and Means 2004); however, a growing share of beneficiaries will be required to pay taxes on their Social Security benefits in the future (Munnell 2003).

\section{Capital Gains and Dividends}

Prior to 2003, corporate dividends were included in AGI and taxed at ordinary income tax rates up to a maximum of 38.6 percent, while long-term capital gains (on assets held one year or more) were subject to an alternative rate schedule with a top tax rate of 20 percent and a 10 percent rate for moderate income taxpayers. 
Under the Jobs and Growth Tax Relief Reconciliation Act of 2003 (JGTRRA), long-term capital gains and dividends were taxed at 15 percent for most taxpayers with these income sources and 5 percent for moderate income taxpayers for the years 2003 through 2007. Capital gains rates were set at 15 percent and 0, respectively, for tax year 2008. The JGTRRA provisions for capital gains and dividends were scheduled to expire in 2009, but the Tax Increase Prevention and Reconciliation Act of 2005 (TIPRA) extended the reductions through the end of 2010.

The lower rates on capital gains and dividends raise the after-tax return to investments and thereby increase the amount of wealth individuals can accumulate outside of retirement accounts at fixed saving rates, compared with prior law. Absent further legislation, 2001 law will be restored in 2011. The top tax rate on long-term capital gains will rise from 15 to 20 percent for most taxpayers and from 0 to 10 percent for moderate income taxpayers. Dividends will be taxed at ordinary income tax rates of up to 39.6 percent (reflecting also the expiration of marginal tax rate cuts in EGTRRA).

\section{METHODOLOGY}

We use the Urban Institute’s Dynamic Simulation of Income Model (DYNASIM3) to evaluate how the tax treatment of saving and Social Security benefits will affect retirement incomes of boomers at age 67-the age by which most individuals will have retired. The model starts with a self-weighting sample of 103,072 individuals from the 1990 to 1993 Survey of Income and Program Participation (SIPP). DYNASIM ages this starting sample in yearly increments to 2050, using parameters estimated from longitudinal data sources. The model integrates many 
important trends and differentials in life course processes, including birth, death, schooling, leaving home, first marriage, remarriage, divorce, disability, work, and earnings.

DYNASIM also simulates the major sources of retirement wealth and income. The model projects lifetime earnings, the timing of retirement and Social Security benefit take-up, pension participation, coverage, and wealth (both defined benefit and defined contribution), and wealth accumulation outside of pensions. DYNASIM also includes federal and state income tax calculators, along with imputations from the IRS Statistics of Income (SOI) public-use file (PUF) of data that are either missing or underestimated in SIPP. These include income from assets (interest, dividends, and capital gains) and itemized deductions. The tax calculators implement current law tax, including the effects of EGTRRA, JGTRRA, TIPRA, the alternative minimum tax (AMT), and the taxation of Social Security benefits and pension income (Bakija 2005). (See Appendix A for more detail on DYNASIM).

\section{Baseline Scenario}

The DYNASIM baseline tax scenario mostly reflects current tax law, including provisions that are scheduled to expire in the future, and is summarized in table 1 . The baseline departs from current tax law in two ways. First, it assumes all price-indexed parameters of the income tax law and (currently unindexed) parameters of the AMT are indexed to changes in the average wage instead of the price level beginning in 2018. In the absence of this assumption, real economic growth would eventually lead to much higher future average income tax burdens. We assume in our baseline that future Congresses will not permit this to happen.

Second, the baseline assumes that Congress will retain the higher temporary AMT exemptions (the AMT patch) for tax year 2006 and index them to changes in the price level between 2006 and 2017 and to wages beginning in 2018. We make this assumption because 
Congress in recent years has always extended the AMT patch when necessary to prevent large numbers of taxpayers from being subject to the AMT. Leiserson and Rohaly (2006) estimate that, if the AMT patch had been allowed to expire, over 23 million individual taxpayers (26 percent) would have paid the AMT in 2007, but Congress extended the patch to tax year 2007 just before the end of 2007.

\section{Policy Simulations}

We simulate how alternative rules for taxing returns to saving and Social Security benefits would affect the incomes at age 67 of boomer cohorts. The scenarios are:

1) Reduce 401(k) Contribution Limits: Beginning in 2002, reduce the contribution limits to those in effect prior to EGTRRA indexed to changes in the price level between 2002 and 2017 and to changes in the average wage after 2017. We also eliminate the age 50 and over baseline catch-up contribution amounts. Individuals continue to save the same amount, but transfer the excess contribution into a non tax-deferred savings account and pay income tax on it. For the non tax-deferred savings account, both the contributions and the returns to the investment are taxed.

2) Reduce Capital Gains and Dividends Tax Rate: Beginning in 2011, permanently extend the lower tax rates on capital gains and dividends in JGTRRA.

3) Index Social Security Thresholds: Beginning in 2007, index the thresholds for including Social Security benefits in AGI to changes in the price level between 2006 and 2017 and to changes in the average wage beginning in 2018. This prevents the gradual erosion of the thresholds over time that characterizes current law.

4) Eliminate Social Security Thresholds: Beginning in 2006, eliminate the thresholds for income taxation of Social Security benefits and include 85 percent of all benefits in AGI. 
This subjects Social Security to approximately the same tax rules as private pension plans, with the share representing return of previously taxed employee contributions taxexempt and the shares representing return of tax-free employer contributions and income in excess of contributions taxable.

For each of these simulations, we examine how individual retirement income changes compared with the baseline. Table 2 summarizes the options.

A major methodological issue is what to assume about how tax-deferred accounts affect saving. Past studies have examined this issue, with some finding little or no effect on saving (Engen, Gale, and Scholz 1996), others finding net increases in saving only for low-income workers (Engen and Gale 2000), and still others finding that contributions to 401(k) plans come in part from current consumption and therefore increase net saving (Poterba, Venti, and Wise 1996). As a starting point, we assume that deposits to accounts all come from other forms of saving, but that individuals save and reinvest any increment of wealth they get from having a higher share of their wealth in tax-deferred accounts. In effect, we hold consumption fixed with respect to policy changes, so that net saving out of current earnings remains fixed, but additional returns on capital investments are saved, not consumed. The effect is that contributions to taxdeferred accounts do increase wealth at retirement, but by less than if contributions came at the expense of current consumption.

To implement this assumption in the model, we assume that differences in taxes paid between the baseline and simulation are invested in stocks and bonds in non tax-deferred accounts in the same proportion and with the same pre-tax rates of return as in the 401(k) taxdeferred accounts. The simulations, therefore, affect not only current year after-tax income, but 
also the wealth that generates future income because after-tax yields are less in the non taxdeferred than in tax-deferred accounts.

We accumulate this account (positive or negative, depending on the simulation), including both contributions (differences in taxes paid) and investment returns, over the individual's lifetime and add it to the DYNASIM baseline wealth. The wealth accumulated from existing assets is reduced by the tax on the asset return. The equation we use to calculate additional taxes on long-term capital gains, dividends, and interest on reinvested wealth is:

$$
\Delta T=\left(r_{E} S_{E}\left(t_{D} D+t_{G}(1-D) G_{R}\right)+r_{B}\left(1-S_{E}\right) t\right) \Delta W
$$

where $\Delta \mathrm{T}$ represents additional taxes on the yield from reinvested wealth, $\mathrm{r}_{\mathrm{E}}$ is the pretax nominal return on equities, $\mathrm{S}_{\mathrm{E}}$ is the share of additional wealth held in equities, $\Delta \mathrm{W}$ represents additional wealth reinvested, $\mathrm{t}_{\mathrm{D}}$ is the individual's marginal tax rate on dividends, $\mathrm{D}$ is the share of total equity return from dividends, $\mathrm{t}_{\mathrm{G}}$ is the individual's marginal tax rate on capital gains, $\mathrm{G}_{\mathrm{R}}$ is the ratio of realized to accrued capital gains, $\mathrm{r}_{\mathrm{B}}$ is the yield on bonds, and $\mathrm{t}$ is the individual's marginal tax rate on ordinary income.

In equation (1) we assume that $\mathrm{D}=.40$ and $\mathrm{G}_{\mathrm{R}}=.50$. The marginal tax rates are determined by simulating the effect of the policy change on taxable income, given the tax laws and other sources of income and deductions.

Our measure of after-tax household income at age 67 is the sum of income from financial assets and retirement accounts, Social Security benefits, DB pension benefits, earnings, Supplemental Security Income (SSI), imputed rental income, and income from non-spouse coresident household members, minus federal and state income taxes. Individuals are the units of observation, but income estimates reflect household income and include income from the spouse, if the individual is married, and non-spouse co-residing adults. We compute each individual's 
income by dividing household income by the number of household members. We report per capita after-tax household income in 2005 dollars by sex, marital status, race and ethnicity, level of education, shared lifetime earnings quintile, and after-tax household income quintile. ${ }^{1}$ Finally, we report simulations for two groups of birth cohorts—leading boomer retirees (born 1946-1950 who turn age 67 in 2013-2017) and trailing boomer retirees (born 1960-1964 who turn age 67 2027-2031). The outcomes are expected to differ between these two groups of cohorts because, compared with leading boomers, trailing boomers will have up to 18 years longer than to accumulate wealth prior to age 67 under each tax reform scenario and will face larger differences between unindexed and indexed Social Security thresholds in retirement.

\section{RESULTS OF SIMULATIONS}

This section describes the effects of alternative tax policies on the incomes of future retirees at age 67 in the 1946-1950 and 1960-64 birth cohorts. We display three tables for each group of cohorts. Tables 3a and 3b display the baseline average after-tax income and for each policy simulation, average after-tax income and the absolute and percentage changes in after-tax income. Tables 4a and 4b show the share who benefit and the absolute and percentage increases in their average after-tax incomes for scenarios that reduce taxes, and the share who lose income and the absolute and percentage declines in their average after-tax incomes for scenarios that increase taxes. ${ }^{2}$ Tables $5 \mathrm{a}$ and $5 \mathrm{~b}$ compare the shares of aggregate income gained or lost for

\footnotetext{
${ }^{1}$ Shared lifetime earnings are the average of wage-indexed shared earnings between ages 22 and 62, where shared earnings are half the total earnings of the couple in the years when the individual is married and his or her own earnings in years when not married.

${ }^{2}$ To eliminate the effects of rounding errors and to remove those not significantly affected by the policy changes, we count as winners and losers only those whose per capita household income at age 67 increases or decreases by at least $\$ 10$ under the simulation.
} 
each population subgroup under the four policy simulations with their shares of aggregate income under the baseline.

\section{Reduce 401(k) Contribution Limits}

Modestly reducing the maximum contribution limit on 401(k) accounts to pre-EGTRRA levels (in real dollars) changes outcomes only slightly because few people currently contribute the maximum amount. The lower limits reduce average retirement incomes by only $\$ 12$ for leading boomers (table 3a). The average reduction is more than four times larger for those in the top quintiles of lifetime earnings and household income, but even they see a loss of less than 0.1 percent of their income. The effect on income is on average over 11 times larger for trailing than for leading boomers and is also concentrated in the top earnings and income quintiles, but even among trailing boomers the average estimated effects are small (table 3b).

The lower limits would reduce retirement income for only 2.9 percent of leading boomers, who would see their income decrease on average by only $\$ 569$, or 0.5 percent of aftertax income (table 4a). The tighter limits mainly affect higher income retirees from wealthier socio-economic groups, who are those most likely to contribute the maximum under the baseline. Married adults, white non-Hispanics, college graduates, and those with the highest lifetime earnings and highest household income are most likely to lose after-tax household income when 401(k) contribution limits are reduced. Still, just 11.3 percent of people in the top household income quintile are projected to experience a loss in their household income and that loss averages $\$ 655$ or 0.5 percent of income. A larger drop in the maximum limit, of course, could have a bigger effect on contributions and through them on the accumulation of retirement wealth. Also, a lower maximum limit would spread the losses to less affluent individuals who now 
contribute less than the pre-EGTRRA contribution limits, but could be affected if the caps on contributions were even tighter.

Losers among trailing boomers would lose more than their leading boomer counterparts because they are more likely to participate in 401(k) plans and to have ever been constrained by contribution limits. Furthermore, trailing boomers will accumulate wealth outside of taxdeferred plans and inside lower-yielding taxable accounts for up to 18 years longer than leading boomers. Overall, restoring the pre-EGTRRA limits would reduce retirement income for 4.1 percent of trailing boomers by an average of $\$ 3,768$ or 1.9 percent of income (table $4 \mathrm{~b})$. Losses for trailing boomers are also concentrated among high income groups, with 15.5 percent of trailing boomers in the top income quintile projected to lose from the reduced contribution limits. Their average decline in after-tax household income is projected to be $\$ 4,620$, a 2.1 percent decrease in their after-tax income.

The highest income boomers are expected to absorb nearly all of the income losses from reducing 401(k) contribution thresholds. We see that leading boomers in the top income quintile, with just over 40 percent of projected aggregate income at age 67 in the baseline scenario, will experience 88 percent of the losses from the decreased contribution limits and similar trailing boomers will experience 96 percent of the losses (tables 5a and 5b). ${ }^{3}$

\footnotetext{
${ }^{3}$ The simulation results show that some individuals and some groups as a whole actually benefit from lower 401(k) contribution limits. This seemingly paradoxical result happens because DYNASIM assigns returns stochastically to investors in 401(k) accounts and some individuals have negative returns on their assets. When returns from assets with losses become taxable because individuals can no longer hold them within tax-deferred accounts, investors can deduct some of their losses (up to \$3000) against other income. In contrast, losses on assets held in retirement accounts cannot be deducted. The result is that individuals with capital losses end up with more wealth by investing outside than inside tax-deferred retirement saving accounts. Appendix B provides an example of how this can occur.
} 


\section{Qualifications}

The estimates in this paper of how recent changes in retirement contribution limits affect retirement income are based on projections of 401(k) contributions from the current version of DYNASIM, which is based on projections of contributions from the 1990-93 SIPP surveys. Recent research using an exact match file of the SIPP with the Detailed Earnings Records (DER) through 2003 finds more people, though still only about 6 percent, contributing the maximum to 401(k) accounts in recent years than in the current DYNASIM projections (Kawachi, Smith, and Toder 2005; Smith et al. 2007). We are currently updating DYNASIM to incorporate these new estimates of 401(k) contributions. With the new estimates, we would expect to find more income of more people affected by restoring pre-2001 real contribution limits than the current model finds. We would still expect to find, based on projections of 401(k) participation and contributions, that the overwhelming share of people with losses are in the top quintile of the income distribution, but we would expect more of the losses would be spread to other groups in the population.

\section{Reduce Capital Gains and Dividends Tax Rate}

The benefits of permanently lowering the top tax rates on capital gains and dividends to 15 percent after 2010 accrue mostly to people in the top quintile of the income distribution (tables 3a and 3b). For leading boomers, average after-tax income increases by 0.9 percent overall, but by 1.9 percent in the top quintile and much less for all other groups. For trailing boomers, aftertax return rises by 2.3 percent in the top quintile, compared with 1.3 percent overall. Other groups with larger than average increases in after-tax income at age 67 for both leading and trailing boomers are white non-Hispanics, college graduates, and individuals in the top quintile of lifetime earnings. 
Changes in the taxation of capital gains and dividends affects slightly more people than any of the other policy options. Overall, 40.4 percent of leading boomers would see their household income increase by an average of $\$ 986$ or 1.5 percent, while 57.6 percent of trailing boomers would gain an average of $\$ 1,205$ or 1.6 percent of after-tax income (tables $4 \mathrm{a}$ and $4 \mathrm{~b}$ ). The groups with the most winners are high socio-economic groups (e.g. white non-Hispanics, college graduates, and those with the highest lifetime earnings and household income), who receive a much larger share of their income from capital gains and dividends than others. For example, 84.5 percent of leading boomers in the highest income quintile are projected to receive an average increase of $\$ 1,848$ (2.1 percent of after-tax income) and 89.2 percent of trailing boomers will receive an average increase of $\$ 3,104$ (2.5 percent of after-tax income). In contrast, only 1 percent of leading boomers in the bottom income quintile receive any benefit and the average benefit for them is just $\$ 108$ (0.6 percent of after-tax income). More trailing boomers in the bottom quintile benefit (11.1 percent), but their average gain (\$134) is smaller as a share of after-tax income ( 0.4 percent) than the gain for leading boomers.

Trailing boomers are more likely than leading boomers to experience an increase in their after-tax income from lower tax rates on capital gains and dividends and gain more income because they have more years to benefit from the higher after-tax investment returns that the lower tax rates produce. Also, while in any year most taxpayers do not have dividend or capital gain income, over many years they have some dividends or capital gains. Although trailing boomers gain more than leading boomers from the lower tax rates on dividends and capital gains, the pattern of relative gains among demographic and income groups within the two groups of cohorts is similar. 
In aggregate, high socio-economic groups are projected to receive most of the additional income generated by lower capital gains and dividends tax rates. For example, the individuals in the top income quintile are projected to receive 86.4 percent of the benefits among leading boomers and 79.9 percent of the benefits among trailing boomers (tables $5 \mathrm{a}$ and $5 \mathrm{~b}$ ).

\section{Index Social Security Thresholds}

Indexing the Social Security thresholds beginning in 2007, raises after-tax income for leading boomers by an average of $\$ 82$ or 0.2 percent of after-tax income and for trailing boomers by $\$ 196$ or 0.4 percent of after-tax income (tables 3a and 3b). For both leading and trailing boomers, percentage increases in after-tax income are much larger in the three middle income quintiles than in either the bottom or top quintiles. Other subgroups who fare relatively well in both leading and trailing boomer cohorts are black non-Hispanics (relative to other racial and ethnic groups), high school graduates (relative to high school dropouts and college graduates), and individuals in the third and fourth quintiles ranked by shared lifetime earnings.

Overall, 21.5 percent of leading boomers would see their household income increase by an average of $\$ 380$ or 1.1 percent of their after-tax income (table 4a). Some individuals in all income groups would benefit from indexed Social Security thresholds, but fewer are in the bottom and top income quintiles than in the middle quintiles. Because most individuals in the bottom quintile have either none or very little of their Social Security benefits included in AGI under current tax law, indexing or increasing the thresholds will not benefit them. Only 0.3 percent of leading boomers in the bottom income quintile are projected to benefit from indexing of the thresholds. Even in cases where they do gain because a portion of their benefit is taxable under current law, their increase in after-tax income is small because they are in a low tax bracket. In the top quintile, most individuals have high enough income that 85 percent of their 
benefits continue to be included in AGI even when the Social Security thresholds are indexed. Indexing the thresholds increases the after-tax income of only 4.8 percent of leading boomers in the top income quintile. In contrast to those in the bottom and top quintiles, leading boomers in the other income groups are much more likely to benefit from indexing because higher threshold levels would keep more of their benefits either totally excluded from AGI or subject to only a 50 percent tax rate.

The benefits of indexing the thresholds are projected to be larger for trailing boomers whose members begin turning 67 in 2027 than for leading boomers who first turn 67 in 2013. This happens because the size of the thresholds in relation to retirement incomes will have many more years to erode for trailing boomers under current law, leaving an increasing number of retirees subject to taxes on their benefits. As a result, indexing Social Security thresholds is projected to increase the after-tax income of 28.9 percent of trailing boomers by an average of \$681 or 1.5 percent of income (table 4b). As with leading boomers, trailing boomers in the three middle income groups are the most likely to gain from indexing and will have the largest gains. But trailing boomers in the bottom quintiles are much more likely to benefit from indexing than their leading boomer counterparts (8.4 versus 0.3 percent winners) and, among winners in the bottom income quintile, trailing boomers average gains over six times those of leading boomers (\$600 versus $\$ 95)$.

Altogether, leading boomers in the three middle income quintiles, with 50.5 percent of baseline after-tax income, are projected to receive 96.3 percent of the benefits from indexing the thresholds — with the majority of benefits (83.3 percent) going to people in the third and fourth income quintiles (table 5a). Trailing boomers in the three middle income quintiles receive a similar share of benefits (93.2 percent) as their leading boomer counterparts; however, the 
benefits are more evenly distributed between the second, third, and fourth income quintiles (table 5b). Additionally, trailing boomers with the lowest income are projected to reap a much larger share of the benefits from indexing the thresholds (5.1 percent) than their leading boomer counterparts ( 0.1 percent).

\section{Eliminate Social Security Thresholds}

Overall, eliminating the thresholds and including 85 percent of all Social Security benefits in income beginning in 2006 would reduce average after-tax income by $\$ 233$ or 0.6 percent for leading boomers and by $\$ 122$ or 0.2 percent for trailing boomers (tables 3a and 3b). In both leading and trailing boomer cohorts, income would fall the most in the second and third quintiles of the income distribution—by 1.6 and 1.5 percent, respectively, for leading boomers and by 0.9 percent and 0.5 percent for trailing boomers. Other relatively big losers in both leading and trailing boomer cohorts are black non-Hispanics (compared with other racial and ethnic groups), high school graduates (compared with high school dropouts and college graduates), and individuals in the second and third quintiles ranked by shared lifetime earnings. Eliminating the thresholds affects earlier cohorts more than later cohorts because, under current law, Social Security thresholds will erode over time, so that eventually the thresholds will virtually disappear with no change in the law.

The number who lose and the losses per affected individual would also be greatest in the middle income quintiles. Eliminating the thresholds would lower household income for 30.5 percent of leading boomers by an average of $\$ 762$ or 2.4 percent (table 4a). Only 10.8 percent of the lowest income individuals and 4.6 percent of the highest income individuals would see their after-tax income at age 67 drop. In contrast, 46.4 percent of those in the second income quintile are projected to lose an average of $\$ 828$ or 3.2 percent of after-tax income, 58.1 percent of those 
in the third income quintile are projected to lose an average of $\$ 866$ or 2.8 percent of after-tax income, and 32.6 percent of those in the fourth income quintile are projected to lose an average of $\$ 626$ or 1.6 percent of after-tax income.

In contrast, eliminating the thresholds will reduce after-tax income at age 67 for only 22.7 percent of trailing boomers by an average of $\$ 539$ or 1.4 percent (table 4b). As with leading boomers, trailing boomers in the three middle income groups are most likely to lose and will experience the largest losses. Trailing boomers in the top quintile, however, are about equally as likely as their leading boomer counterparts to lose income from eliminating the thresholds for taxing benefits (compare 4.3 percent with 4.6 percent), but they can expect their average losses to be around half that of leading boomers ( $\$ 177$ compared with \$365).

Altogether, leading boomers in the three middle income groups have 50.5 percent of projected aggregate income at age 67 in the baseline scenario, but will bear 94.0 percent of income losses if the thresholds for taxing Social Security benefits were eliminated (table 5a). Trailing boomers in the middle income groups have nearly as much of the projected aggregate income in the baseline scenario as leading boomers (49.0 percent) and will bear a slightly smaller share of the income losses (88.5 percent).

\section{CONCLUSIONS}

Provisions of the federal income tax affect both the buildup of retirement assets during workers' careers and their after-tax income following retirement. This paper focuses on the effects of three aspects of the tax law with potentially large effects on after-tax incomes of retirees - the tax preferences for employer-sponsored deferred contribution plans, the taxation of equity investment income (capital gains and dividends) outside of tax-deferred retirement saving plans, 
and the income tax treatment of Social Security benefits. We simulate the effects of recent changes in contribution limits to retirement plans and tax rates on capital gains and dividends and potential changes in the taxation of Social Security benefits on incomes of boomers at age 67 using a micro-simulation model that projects future incomes in retirement.

For changes in contribution limits to retirement plans and tax rates on capital gains and dividends, we simulate the effects of tax legislation enacted since 2001. We find that restoring the pre-2001 contribution limits (indexed for inflation) mostly affects high-income retirees (who were high earning workers), but has very little effect on their after-tax incomes because, even at high incomes, very few workers are currently constrained by the limits. Extending the tax cuts on dividends and capital gains enacted in 2003 past its expiration date (the end of 2010) would have larger aggregate benefits for leading boomers and smaller aggregate benefits for trailing boomers than increasing contribution limits, but the benefits would also be concentrated among higher-income retirees, who have the most capital gains and dividends (and had the most gains and dividends in their working years).

In contrast, changes in the thresholds for taxing Social Security benefits mostly affect middle-income retirees. We examined two possible changes—indexing the thresholds for taxing benefits to changes in the CPI through 2017 (and to wages after 2017) and eliminating the thresholds completely and taxing all benefits. Both changes have less effect on low-income and high-income than on middle-income retirees. Low-income retirees do not benefit much from indexing because most of them do not pay tax on their benefits even with the unindexed thresholds. They also do not pay much additional tax from full inclusion of benefits because they are in a low (or zero) income tax bracket even with benefits included in taxable income. High-income retirees do not benefit much from indexing because their incomes would remain 
above the threshold for taxing 85 percent of benefits, even with the higher thresholds. They also do not pay much additional tax when the thresholds are eliminated because many are already paying tax on 85 percent of benefits.

Most of the policy changes affect trailing boomers (those born between 1960 and 1964) much more than they affect leading boomers (those born between 1946 and 1950). Trailing boomers have up to 18 years longer than leading boomers to accumulate wealth prior to age 67 , so policies that raise or lower after-tax returns on saving affect them relatively more. Indexing Social Security thresholds for inflation also affects trailing boomers more than leading boomers because trailing boomers reach age 67 later, after indexing has had more years to change threshold amounts before taking benefits. The proposal to tax 85 percent of all benefits with no thresholds, however, increases taxes more for leading boomers than for trailing boomers because under current law, which does not index thresholds, a larger share of trailing boomers' benefits will already be taxable over time, making a move to full inclusion less of a change for them.

As policymakers are forced to confront shortfalls in Social Security financing, they could consider income tax changes as an alternative to or in conjunction with reducing benefits or increasing payroll taxes. Different income tax changes, however, will have substantially different effects on the income distribution of future retirees. Proposals to change the income thresholds for exempting Social Security benefits from income tax will have the largest impact on middle-income boomers. In contrast, proposals that change the tax incentives for retirement saving or reduce taxes on capital gains and dividends will mostly affect the highest income boomers. Before enacting proposals that reduce retirement incomes of low- and middle-income retirees, policymakers could consider changing income tax rules that benefit the more affluent future retirees. 


\section{REFERENCES}

Bakija, Jon. 2005. "Documentation for IncTaxCalc: A Federal-State Personal Income Tax Calculator Covering the Years 1900-2002.” Unpublished Manuscript.

Burman, Leonard E., William G. Gale, and Jeffrey Rohaly. 2003. “The Expanding Reach of the Individual Alternative Minimum Tax.” Journal of Economic Perspectives 17(2): 173-186.

Burman, Leonard E., William G. Gale, Matthew Hall, and Peter R. Orszag. 2006. "Distributional Effects of Defined Contribution Plans and Individual Retirement Arrangements.” In Government Spending on the Elderly, edited by Dimitri B. Papadimitriou (69-111). New York: Palgrave Macmillan.

Committee on Ways and Means. 2004. "2004 Green Book: Background Material and Data on the Programs within the Jurisdiction of the Committee on Ways and Means." Washington, DC: U.S. Government Printing Office. http://waysandmeans.house.gov/Documents.asp?section=813. (Accessed January 10, 2008.)

Engen, Eric M., and William G. Gale. 2000. "The Effects of 401(k) Plans on Household Wealth: Differences Across Earnings Groups.” NBER Working Paper No. 8032. Cambridge, MA: National Bureau of Economic Research.

Engen, Eric M., William G. Gale, and John Karl Scholz. 1996. "The Illusory Effects of Saving Incentives on Saving.” Journal of Economic Perspectives 10(4): 113-38.

Favreault, Melissa M. and Karen E. Smith. 2004. "A Primer on the Dynamic Simulation of Income Model (DYNASIM3).” The Retirement Project Discussion Paper No. 0204. Washington, DC: The Urban Institute.

Investment Company Institute. 2006. “401(k) Plans: A 25-Year Retrospective.” Research Perspective 12(2): 1-40. Washington, DC: Investment Company Institute. http://www.ici.org/pdf/per12-02.pdf. (Accessed January 8, 2008.)

Investment Company Institute. 2007. “2007 Investment Company Fact Book.” Washington, DC: Investment Company Institute. http://www.icifactbook.org/index.html. (Accessed January 8, 2008.)

Johnson, Richard W., Leonard E. Burman, and Deborah I. Kobes. 2004. "Annuitized Wealth at Older Ages: Evidence from the Health and Retirement Study." Final report to the Employee Benefits Security Administration, U.S. Department of Labor. Washington, D.C.: The Urban Institute. http://www.urban.org/UploadedPDF/411000_annuitized_wealth.pdf. (Accessed January 8, 2008.) 
Kawachi, Janette, Karen E. Smith, and Eric J. Toder. 2005. "Making Maximum Use of Tax-Deferred Retirement Accounts.” CRR Working Paper 2005-19. Chestnut Hill, MA: Center for Retirement Research at Boston College. http://crr.bc.edu/images/stories/Working_Papers/WP_2005-19.pdf. (Accessed January 8, 2008.)

Leiserson, Greg and Jeffrey Rohaly. 2006. “The Alternative Minimum Tax: Historical Data and Projections.” http://www.taxpolicycenter.org/UploadedPDF/901012_individual_amt.pdf. (Accessed January 8, 2008.)

Munnell, Alicia H. 2003. “The Declining Role of Social Security.” Just the Facts on Retirement Issues No. 6. Chestnut Hill, MA: Center for Retirement Research at Boston College. http://crr.bc.edu/images/stories/Just\%20the\%20Facts/jtf_6.pdf. (Accessed January 8, 2008.)

Poterba, James M., Steven F. Venti, and David A. Wise. 1996. "How Retirement Programs Increase Savings.” Journal of Economic Perspectives. 10(4): 91-112.

Smith, Karen E., Melissa M. Favreault, Caroline Ratcliffe, Barbara, Butrica, Eric Toder, and Jon Bakija. 2007. "Modeling in the Near Term 5.” Urban Institute. Final Report to Social Security Administration. October.

VanDerhei, Jack, Russell Galer, Carol Quick, and John Rea. 1999. “401(k) Plan Asset Allocation, Account Balances, and Loan Activity.” EBRI Issue Brief No. 205. Washington, DC: Employee Benefit Research Institute. 


\section{APPENDIX A}

This appendix provides details on the DYNASIM modules directly related to this report. For a more complete description of DYNASIM, see Favreault and Smith (2004).

\section{Retirement Accounts}

DYNASIM projects amounts in defined contribution plans. Pensions are based on an individual's entire work history (real and simulated) up to the projected retirement date. Baseline data regarding pension coverage on current and past jobs and DC account balances are based on SIPP self-reports. To impute future job changes and pension coverage on future jobs, DYNASIM incorporates data on synthetic work histories from the Policy Simulation Group’s PENSIM model, developed for the Department of Labor, Pension and Welfare Benefits Administration. Starting with an individual's initial account balance from the SIPP data base, DYNASIM projects future employee contributions, employer matching contributions, and yields on account assets to calculate future account balances.

In projecting the accumulation of DC wealth, DYNASIM imputes future contribution rates and asset allocations that vary by age and are based on EBRI/ICI data on 401(k) asset allocations (VanDerhei et al. 1999). DYNASIM maintains self-reported contribution differentials compared with EBRI/ICI calculated averages over time, with large initial contributors in the base data file depositing more and small contributors depositing less in 401(k) accounts relative to average contribution rates by age and earnings group. Previous non-contributors become participants based on take-up rates by age and earnings group and deposit the average amount for their age/earnings group. Employer contributions are assigned as a function of the employee contributions and imputed employer match rates. 
DYNASIM varies the proportion of contributions and balances allocated to equities by age category. Then, every five years, the model re-balances the portfolios according to the allocation strategy for the individual's attained age category. For example, individuals in their 20s will hold about 76 percent of their portfolio in stocks and 24 percent in bonds. In their 60s, they will hold about 53 percent of their portfolio in stocks and 47 percent in bonds, reflecting the reduced ability to bear risk as retirement approaches. Subsequent contributions are allocated to match the allocation strategy of the attained age, if different.

DYNASIM increases DC account balances every year using historical price changes and historical returns for stocks and bonds. Investment experience varies for each individual by setting the rates stochastically, using historical standard deviations. For years after 2003, DYNASIM assumes a CPI growth rate of 2.8 percent (the growth rate assumed by the Social Security Administration's Office of the Chief Actuary [OCACT]), a nominal rate of return for stocks of 9.5 percent, and a nominal rate of return for bonds of 6.19 percent. Future rates of return for individuals vary by a standard deviation of 17.28 percent for stocks and 2.14 percent for bonds. One percent is subtracted from each of the stock and bond real rates of return to reflect administrative costs.

\section{Social Security Benefits}

DYNASIM includes a detailed Social Security benefit calculator that uses earnings and marital histories to estimate Social Security benefits—either retired-worker, spouse, or survivor benefits. The benefit calculator is based on the 2005 OCACT assumptions about future price and wage growth. In each year, from the projected year of first benefit receipt until the projected year of death, DYNASIM computes a respondent's Social Security benefit that reflects his or her earnings and marital history at that point in time. The calculator first establishes benefit 
eligibility based on personal characteristics such as age, number of covered quarters, disability status, marital status, and length of marriage. For those who qualify, the model computes Social Security benefits, including retired worker, spouse, divorced spouse, and survivor benefits. The calculator then checks an individual's take-up age against his or her normal retirement age (NRA), reducing benefits for those who retire before their NRA and increasing benefits for those who retire later. Social Security estimates are based on the assumption that current-law benefits will be payable throughout the projection period. Although OCACT projects that the OASDI Trust Funds will not be exhausted until 2041, it is possible that the prospect of that happening could cause benefits to be lowered before then. Nonetheless, we assume future retirees will receive the current law benefits they were promised at least through 2031.

\section{Financial Assets}

DYNASIM projects financial assets (i.e., stock, mutual fund, and bond values and checking, savings, money market, and certificate of deposit account balances, less unsecured debt) on the basis of historical savings patterns. Initial wealth is based on SIPP self-reports. Then the Panel Study of Income Dynamics (PSID) is used to estimate wealth from the age at the SIPP interview to age 50, the Health and Retirement Study (HRS) is used to estimate asset accumulations from age 51 to retirement, and the SIPP is used to estimate asset spend-down from retirement until death. Because of large differences in individual saving behavior, use of longitudinal data is vital for estimating wealth changes over time. The PSID provides the best source of longitudinal wealth data for younger ages and the HRS provides the best source of longitudinal wealth data for individuals near retirement.

DYNASIM projects financial assets using a random-effects model that accounts for the unobserved heterogeneity that is typical of wealth measures. The model is estimated separately 
by marital status based on age of household head, race, family size, birth cohort, dual-earner status, pension coverage, and earnings.

\section{Taxes}

DYNASIM has the capacity to estimate payroll taxes, as well as state and federal income taxes. The DYNASIM tax calculator accurately models current law taxes including EGTRRA, JGTRRA, the AMT, and the taxation of Social Security benefits and pension income. The tax calculator also simulates future tax law. For short-term projections (through 2017), it holds constant the current law tax rates and adjusts the brackets as appropriate for expected inflation. It holds the Social Security taxation thresholds at their current law values, since these are not indexed for inflation. The calculator also price indexes the provisions of the alternative minimum tax (AMT) beyond the current period, even though these provisions are not currently indexed. Without this adjustment, many middle-class taxpayers would end up paying the AMT (Burman, Gale, and Rohaly 2003). Since wages are expected to increase faster than prices, the tax calculator indexes the brackets and provisions of the AMT to wages instead of prices for the long-term projections (after 2017). Doing this will avoid real-bracket creep and prevent the ratio of taxes to gross domestic product (GDP) from rising steadily over time. It also continues to hold the Social Security taxation thresholds at their current law values. 


\section{APPENDIX B}

Raising contribution limits in retirement accounts can generate losers when individuals have negative asset returns. Similarly, reducing contribution limits in retirement accounts can generate winners under similar circumstances.

This appendix shows a simplified calculation of after-tax returns for savings inside and outside of retirement accounts under the baseline and two alternative tax scenarios assuming first positive asset returns and then negative asset returns. It illustrates how variable asset returns and asset taxation can affect asset buildup over time.

In the baseline scenario, the individual has equal shares of assets outside and inside retirement accounts. At time $t_{1}$, he has $\$ 20,000$ of savings ( $\$ 10,000$ in assets outside retirement accounts and \$10,000 in assets inside retirement accounts). In the top panel, he earns a positive 5 percent rate of return on his investments - a gain of \$500 in both his financial assets and retirement account. We assume that he saves all of his investment gains and is in the 15 percent tax bracket. Because his asset gain outside of the retirement account is taxed, his financial assets increase only by the after-tax return of $\$ 425$ to $\$ 10,425$. But because his asset gain in the retirement account is not taxed, his retirement account increases by the full $\$ 500$ to $\$ 10,500$. Consequently, his combined net assets at time $t_{2}$ are $\$ 20,925$.

In the bottom panel, the individual earns a negative 5 percent rate of return on his investments — a loss of $\$ 500$ in both his financial assets and retirement account. Because his asset losses outside the retirement account can be offset with positive taxable income, his net financial assets decrease only by $\$ 425$ to $\$ 9,575$. However, his asset losses in the retirement account can not be offset and so his retirement account decreases by the full $\$ 500$ to $\$ 9,500$. Consequently, his combined net assets at time $t_{2}$ are $\$ 19,075$. 
In column 2 (extra saving in retirement accounts), the individual saves more inside his retirement account. His total assets at time $t_{1}$ are the same as the baseline, but he has $\$ 500$ less in financial assets and $\$ 500$ more in his retirement account. If he earns a positive rate of return, his net wealth at time $t_{2}$ increases by $\$ 4$ over the baseline because he holds more assets inside taxdeferred retirement accounts. If he earns a negative rate of return, his net wealth at time $t_{2}$ decreases by $\$ 4$ relative to the baseline because less of his combined losses can be offset with positive taxable income.

In column 3 (extra saving outside retirement accounts), the individual saves less inside his retirement account. Again, his total assets at time $t_{1}$ are the same as the baseline, but he has $\$ 500$ more in financial assets and $\$ 500$ less in his retirement account. With positive asset returns, he loses $\$ 4$ relative to the baseline because he holds less assets inside tax-deferred retirement accounts. With negative asset returns, however, he gains $\$ 4$ relative to the baseline because more of his combined losses can be offset with positive taxable income.

Generally, asset returns are positive and the longer assets are held, the gains generally exceed the losses. This example merely illustrates how the tax system can act as an insurance policy for investment returns. 
Table 1. Tax Parameters for the Baseline Scenario

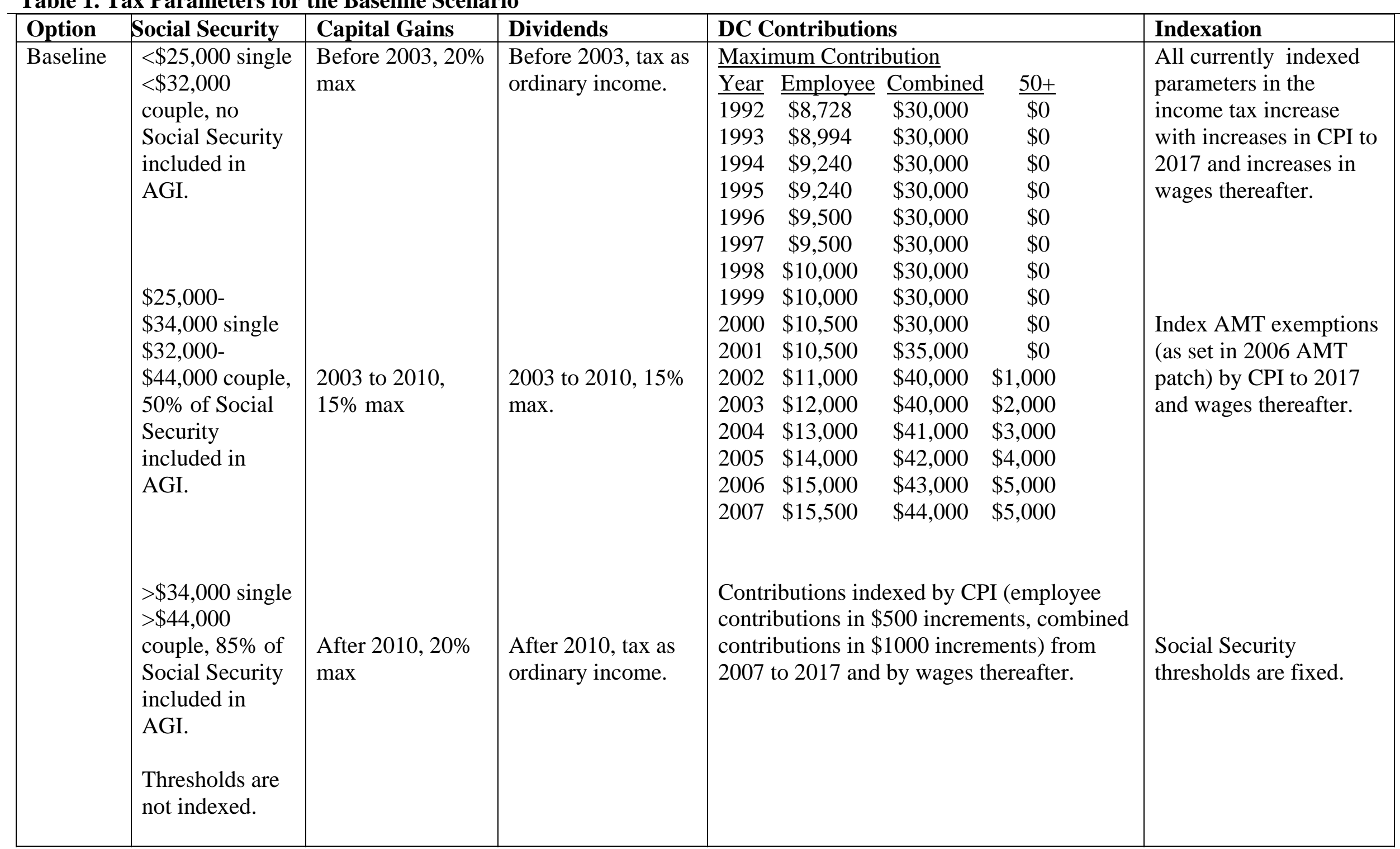

Notes: AGI is adjusted gross income. CPI is the current price index. AMT is the alternative minimum tax. 
Table 2. Tax Parameters of the Alternate Simulations

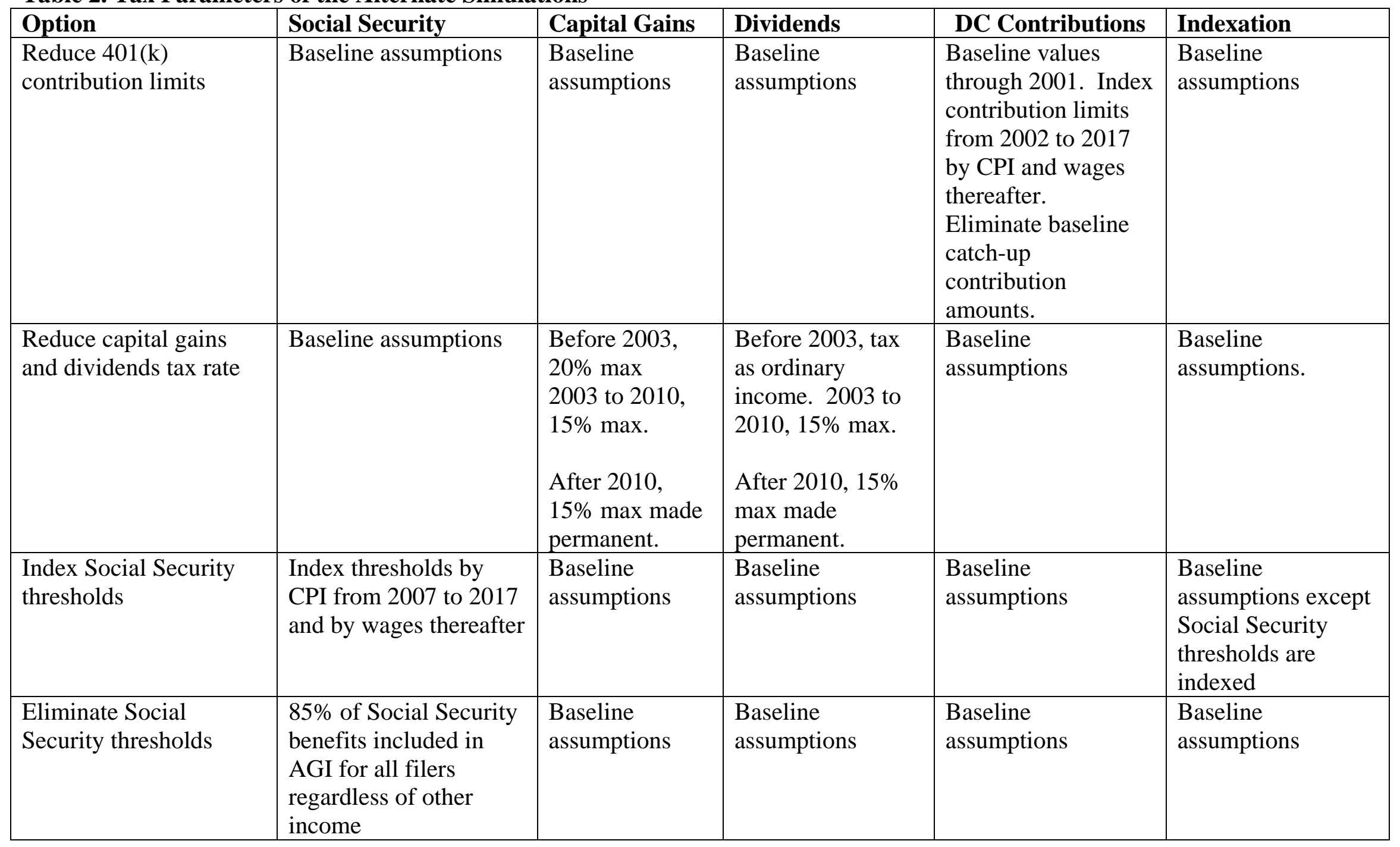


Table 3a. Per Capita After-Tax Household Income Among Adults Age 67 Under Baseline and Alternative Tax Scenarios 1946-1950 Birth Cohorts

\begin{tabular}{|c|c|c|c|c|c|c|c|c|c|c|c|c|c|}
\hline & \multirow[t]{2}{*}{ Baseline } & \multicolumn{9}{|c|}{$\begin{array}{c}\text { Reduce Capital Gains/Dividends } \\
\text { Tax Rate }\end{array}$} & \multicolumn{3}{|c|}{$\begin{array}{c}\text { Eliminate Social Security } \\
\text { Thresholds } \\
\end{array}$} \\
\hline & & \multicolumn{3}{|c|}{ Change in } & \multicolumn{3}{|c|}{ Change in } & \multicolumn{3}{|c|}{ Change in } & \multicolumn{3}{|c|}{ Change in } \\
\hline Total & $\$ 41,221$ & $\$ 41,209$ & $-\$ 12$ & $0.0 \%$ & $\$ 41,582$ & $\$ 361$ & $0.9 \%$ & $\$ 41,303$ & $\$ 82$ & $0.2 \%$ & $\$ 40,988$ & $-\$ 233$ & $-0.6 \%$ \\
\hline $\begin{array}{l}\text { Sex } \\
\text { Female } \\
\text { Male }\end{array}$ & $\begin{array}{l}\$ 40,934 \\
\$ 41,561\end{array}$ & $\begin{array}{l}\$ 40,926 \\
\$ 41,544\end{array}$ & $\begin{array}{l}-\$ 8 \\
-\$ 17\end{array}$ & $\begin{array}{l}0.0 \% \\
0.0 \%\end{array}$ & $\begin{array}{l}\$ 41,181 \\
\$ 42,056\end{array}$ & $\begin{array}{l}\$ 247 \\
\$ 495\end{array}$ & $\begin{array}{l}0.6 \% \\
1.2 \%\end{array}$ & $\begin{array}{l}\$ 41,017 \\
\$ 41,641\end{array}$ & $\begin{array}{l}\$ 83 \\
\$ 80\end{array}$ & $\begin{array}{l}0.2 \% \\
0.2 \%\end{array}$ & $\begin{array}{l}\$ 40,698 \\
\$ 41,332\end{array}$ & $\begin{array}{l}-\$ 236 \\
-\$ 229\end{array}$ & $\begin{array}{l}-0.6 \% \\
-0.6 \%\end{array}$ \\
\hline $\begin{array}{l}\text { Marital Status } \\
\text { Married } \\
\text { Widowed } \\
\text { Divorced } \\
\text { Never married }\end{array}$ & $\begin{array}{l}\$ 39,785 \\
\$ 49,640 \\
\$ 39,463 \\
\$ 43,133\end{array}$ & $\begin{array}{l}\$ 39,773 \\
\$ 49,615 \\
\$ 39,459 \\
\$ 43,127\end{array}$ & $\begin{array}{l}-\$ 12 \\
-\$ 25 \\
-\$ 3 \\
-\$ 6\end{array}$ & $\begin{array}{c}0.0 \% \\
-0.1 \% \\
0.0 \% \\
0.0 \%\end{array}$ & $\begin{array}{l}\$ 40,200 \\
\$ 50,041 \\
\$ 39,590 \\
\$ 43,470\end{array}$ & $\begin{array}{l}\$ 414 \\
\$ 400 \\
\$ 128 \\
\$ 337\end{array}$ & $\begin{array}{l}1.0 \% \\
0.8 \% \\
0.3 \% \\
0.8 \%\end{array}$ & $\begin{array}{l}\$ 39,868 \\
\$ 49,717 \\
\$ 39,551 \\
\$ 43,199\end{array}$ & $\begin{array}{l}\$ 83 \\
\$ 76 \\
\$ 88 \\
\$ 67\end{array}$ & $\begin{array}{l}0.2 \% \\
0.2 \% \\
0.2 \% \\
0.2 \%\end{array}$ & $\begin{array}{l}\$ 39,561 \\
\$ 49,346 \\
\$ 39,234 \\
\$ 42,927\end{array}$ & $\begin{array}{l}-\$ 224 \\
-\$ 295 \\
-\$ 229 \\
-\$ 206\end{array}$ & $\begin{array}{l}-0.6 \% \\
-0.6 \% \\
-0.6 \% \\
-0.5 \%\end{array}$ \\
\hline $\begin{array}{l}\text { Race/Ethnicity } \\
\text { White, non-Hispanic } \\
\text { Black, non-Hispanic } \\
\text { Hispanic } \\
\text { Asian/Native American }\end{array}$ & $\begin{array}{l}\$ 44,716 \\
\$ 29,291 \\
\$ 27,614 \\
\$ 39,186\end{array}$ & $\begin{array}{l}\$ 44,703 \\
\$ 29,291 \\
\$ 27,610 \\
\$ 39,149\end{array}$ & $\begin{array}{l}-\$ 13 \\
\$ 0 \\
-\$ 4 \\
-\$ 36\end{array}$ & $\begin{array}{c}0.0 \% \\
0.0 \% \\
0.0 \% \\
-0.1 \%\end{array}$ & $\begin{array}{l}\$ 45,171 \\
\$ 29,335 \\
\$ 27,663 \\
\$ 39,383\end{array}$ & $\begin{array}{l}\$ 455 \\
\$ 45 \\
\$ 50 \\
\$ 198\end{array}$ & $\begin{array}{l}1.0 \% \\
0.2 \% \\
0.2 \% \\
0.5 \%\end{array}$ & $\begin{array}{l}\$ 44,802 \\
\$ 29,384 \\
\$ 27,670 \\
\$ 39,235\end{array}$ & $\begin{array}{l}\$ 87 \\
\$ 94 \\
\$ 57 \\
\$ 49\end{array}$ & $\begin{array}{l}0.2 \% \\
0.3 \% \\
0.2 \% \\
0.1 \%\end{array}$ & $\begin{array}{l}\$ 44,473 \\
\$ 28,988 \\
\$ 27,458 \\
\$ 39,038\end{array}$ & $\begin{array}{l}-\$ 242 \\
-\$ 303 \\
-\$ 156 \\
-\$ 148\end{array}$ & $\begin{array}{l}-0.5 \% \\
-1.0 \% \\
-0.6 \% \\
-0.4 \%\end{array}$ \\
\hline $\begin{array}{l}\text { Education } \\
\text { High school dropout } \\
\text { High school graduate } \\
\text { College graduate }\end{array}$ & $\begin{array}{l}\$ 22,953 \\
\$ 35,712 \\
\$ 59,901\end{array}$ & $\begin{array}{l}\$ 22,951 \\
\$ 35,705 \\
\$ 59,876\end{array}$ & $\begin{array}{l}-\$ 2 \\
-\$ 8 \\
-\$ 25\end{array}$ & $\begin{array}{l}0.0 \% \\
0.0 \% \\
0.0 \%\end{array}$ & $\begin{array}{l}\$ 22,988 \\
\$ 35,868 \\
\$ 60,799\end{array}$ & $\begin{array}{c}\$ 35 \\
\$ 156 \\
\$ 898\end{array}$ & $\begin{array}{l}0.2 \% \\
0.4 \% \\
1.5 \%\end{array}$ & $\begin{array}{l}\$ 22,992 \\
\$ 35,802 \\
\$ 59,986\end{array}$ & $\begin{array}{l}\$ 39 \\
\$ 90 \\
\$ 85\end{array}$ & $\begin{array}{l}0.2 \% \\
0.3 \% \\
0.1 \%\end{array}$ & $\begin{array}{l}\$ 22,804 \\
\$ 35,436 \\
\$ 59,715\end{array}$ & $\begin{array}{l}-\$ 149 \\
-\$ 276 \\
-\$ 187\end{array}$ & $\begin{array}{l}-0.6 \% \\
-0.8 \% \\
-0.3 \%\end{array}$ \\
\hline $\begin{array}{l}\text { Lifetime Earnings } \\
\text { 1st Quintile } \\
\text { 2nd Quintile } \\
\text { 3rd Quintile } \\
\text { 4th Quintile } \\
\text { 5th Quintile }\end{array}$ & $\begin{array}{l}\$ 19,459 \\
\$ 25,578 \\
\$ 34,967 \\
\$ 48,783 \\
\$ 77,334\end{array}$ & $\begin{array}{l}\$ 19,459 \\
\$ 25,578 \\
\$ 34,964 \\
\$ 48,772 \\
\$ 77,289\end{array}$ & $\begin{array}{l}\$ 0 \\
\$ 0 \\
-\$ 3 \\
-\$ 11 \\
-\$ 46\end{array}$ & $\begin{array}{l}0.0 \% \\
0.0 \% \\
0.0 \% \\
0.0 \% \\
-0.1 \%\end{array}$ & $\begin{array}{l}\$ 19,474 \\
\$ 25,611 \\
\$ 35,066 \\
\$ 49,125 \\
\$ 78,650\end{array}$ & $\begin{array}{c}\$ 15 \\
\$ 33 \\
\$ 100 \\
\$ 342 \\
\$ 1,315\end{array}$ & $\begin{array}{l}0.1 \% \\
0.1 \% \\
0.3 \% \\
0.7 \% \\
1.7 \%\end{array}$ & $\begin{array}{l}\$ 19,476 \\
\$ 25,641 \\
\$ 35,088 \\
\$ 48,912 \\
\$ 77,414\end{array}$ & $\begin{array}{c}\$ 17 \\
\$ 63 \\
\$ 121 \\
\$ 128 \\
\$ 80\end{array}$ & $\begin{array}{l}0.1 \% \\
0.2 \% \\
0.3 \% \\
0.3 \% \\
0.1 \%\end{array}$ & $\begin{array}{l}\$ 19,340 \\
\$ 25,291 \\
\$ 34,622 \\
\$ 48,510 \\
\$ 77,197\end{array}$ & $\begin{array}{l}-\$ 120 \\
-\$ 287 \\
-\$ 345 \\
-\$ 273 \\
-\$ 137\end{array}$ & $\begin{array}{l}-0.6 \% \\
-1.1 \% \\
-1.0 \% \\
-0.6 \% \\
-0.2 \%\end{array}$ \\
\hline $\begin{array}{l}\text { Household Income } \\
\text { 1st Quintile } \\
\text { 2nd Quintile } \\
\text { 3rd Quintile } \\
\text { 4th Quintile } \\
\text { 5th Quintile }\end{array}$ & $\begin{array}{l}\$ 17,991 \\
\$ 24,512 \\
\$ 33,327 \\
\$ 46,097 \\
\$ 84,195\end{array}$ & $\begin{array}{l}\$ 17,991 \\
\$ 24,512 \\
\$ 33,326 \\
\$ 46,091 \\
\$ 84,142\end{array}$ & $\begin{array}{l}\$ 0 \\
\$ 0 \\
-\$ 1 \\
-\$ 6 \\
-\$ 53\end{array}$ & $\begin{array}{c}0.0 \% \\
0.0 \% \\
0.0 \% \\
0.0 \% \\
-0.1 \%\end{array}$ & $\begin{array}{l}\$ 17,992 \\
\$ 24,534 \\
\$ 33,386 \\
\$ 46,261 \\
\$ 85,753\end{array}$ & $\begin{array}{c}\$ 1 \\
\$ 22 \\
\$ 59 \\
\$ 164 \\
\$ 1,558\end{array}$ & $\begin{array}{l}0.0 \% \\
0.1 \% \\
0.2 \% \\
0.4 \% \\
1.9 \%\end{array}$ & $\begin{array}{l}\$ 17,992 \\
\$ 24,565 \\
\$ 33,513 \\
\$ 46,252 \\
\$ 84,210\end{array}$ & $\begin{array}{c}\$ 0 \\
\$ 53 \\
\$ 186 \\
\$ 155 \\
\$ 15\end{array}$ & $\begin{array}{l}0.0 \% \\
0.2 \% \\
0.6 \% \\
0.3 \% \\
0.0 \%\end{array}$ & $\begin{array}{l}\$ 17,937 \\
\$ 24,128 \\
\$ 32,824 \\
\$ 45,893 \\
\$ 84,178\end{array}$ & $\begin{array}{c}-\$ 54 \\
-\$ 384 \\
-\$ 503 \\
-\$ 204 \\
-\$ 17\end{array}$ & $\begin{array}{c}-0.3 \% \\
-1.6 \% \\
-1.5 \% \\
-0.4 \% \\
0.0 \%\end{array}$ \\
\hline
\end{tabular}

Notes: Sample includes adults born 1946 to 1950. Dollar amounts are expressed in 2005 dollars.

Source: Authors' tabulations of DYNASIM3 (see text for details). 
Table 3b. Per Capita After-Tax Household Income Among Adults Age 67 Under Baseline and Alternative Tax Scenarios 1960-1964 Birth Cohorts

\begin{tabular}{|c|c|c|c|c|c|c|c|c|c|c|c|c|c|}
\hline & Baseline & \multicolumn{6}{|c|}{$\begin{array}{c}\text { Reduce Capital Gains/Dividends } \\
\text { Tax Rate } \\
\end{array}$} & \multicolumn{3}{|c|}{ Index Social Security Thresholds } & \multicolumn{3}{|c|}{$\begin{array}{c}\text { Eliminate Social Security } \\
\text { Thresholds } \\
\end{array}$} \\
\hline & Mean & Mean & $\begin{array}{c}\text { Change in } \\
\text { Level }\end{array}$ & \% Change & Mean & $\begin{array}{c}\text { Change ir } \\
\text { Level }\end{array}$ & \% Change & Mean & $\begin{array}{c}\text { Change in } \\
\text { Level }\end{array}$ & \% Change & Mean & $\begin{array}{c}\text { Change in } \\
\text { Level }\end{array}$ & \% Change \\
\hline Total & $\$ 54,209$ & $\$ 54,066$ & $-\$ 143$ & $-0.3 \%$ & $\$ 54,888$ & $\$ 680$ & $1.3 \%$ & $\$ 54,405$ & $\$ 196$ & $0.4 \%$ & $\$ 54,087$ & $-\$ 122$ & $-0.2 \%$ \\
\hline $\begin{array}{l}\text { Sex } \\
\text { Female } \\
\text { Male }\end{array}$ & $\begin{array}{l}\$ 56,323 \\
\$ 51,783\end{array}$ & $\begin{array}{l}\$ 56,189 \\
\$ 51,629\end{array}$ & $\begin{array}{l}-\$ 134 \\
-\$ 154\end{array}$ & $\begin{array}{l}-0.2 \% \\
-0.3 \%\end{array}$ & $\begin{array}{l}\$ 57,031 \\
\$ 52,430\end{array}$ & $\begin{array}{l}\$ 708 \\
\$ 647\end{array}$ & $\begin{array}{l}1.3 \% \\
1.2 \%\end{array}$ & $\begin{array}{l}\$ 56,525 \\
\$ 51,973\end{array}$ & $\begin{array}{l}\$ 202 \\
\$ 190\end{array}$ & $\begin{array}{l}0.4 \% \\
0.4 \%\end{array}$ & $\begin{array}{l}\$ 56,196 \\
\$ 51,666\end{array}$ & $\begin{array}{l}-\$ 126 \\
-\$ 117\end{array}$ & $\begin{array}{l}-0.2 \% \\
-0.2 \%\end{array}$ \\
\hline $\begin{array}{l}\text { Marital Status } \\
\text { Married } \\
\text { Widowed } \\
\text { Divorced } \\
\text { Never married }\end{array}$ & $\begin{array}{l}\$ 49,458 \\
\$ 73,409 \\
\$ 54,700 \\
\$ 58,935\end{array}$ & $\begin{array}{l}\$ 49,358 \\
\$ 73,121 \\
\$ 54,509 \\
\$ 58,781\end{array}$ & $\begin{array}{l}-\$ 101 \\
-\$ 288 \\
-\$ 191 \\
-\$ 154\end{array}$ & $\begin{array}{l}-0.2 \% \\
-0.4 \% \\
-0.3 \% \\
-0.3 \%\end{array}$ & $\begin{array}{l}\$ 50,065 \\
\$ 74,362 \\
\$ 55,394 \\
\$ 59,698\end{array}$ & $\begin{array}{l}\$ 607 \\
\$ 953 \\
\$ 693 \\
\$ 763\end{array}$ & $\begin{array}{l}1.2 \% \\
1.3 \% \\
1.3 \% \\
1.3 \%\end{array}$ & $\begin{array}{l}\$ 49,631 \\
\$ 73,659 \\
\$ 54,920 \\
\$ 59,166\end{array}$ & $\begin{array}{l}\$ 173 \\
\$ 250 \\
\$ 220 \\
\$ 231\end{array}$ & $\begin{array}{l}0.4 \% \\
0.3 \% \\
0.4 \% \\
0.4 \%\end{array}$ & $\begin{array}{l}\$ 49,349 \\
\$ 73,236 \\
\$ 54,573 \\
\$ 58,806\end{array}$ & $\begin{array}{l}-\$ 109 \\
-\$ 173 \\
-\$ 127 \\
-\$ 129\end{array}$ & $\begin{array}{l}-0.2 \% \\
-0.2 \% \\
-0.2 \% \\
-0.2 \%\end{array}$ \\
\hline $\begin{array}{l}\text { Race/Ethnicity } \\
\text { White, non-Hispanic } \\
\text { Black, non-Hispanic } \\
\text { Hispanic } \\
\text { Asian/Native American }\end{array}$ & $\begin{array}{l}\$ 59,175 \\
\$ 44,756 \\
\$ 38,978 \\
\$ 52,787\end{array}$ & $\begin{array}{l}\$ 58,998 \\
\$ 44,648 \\
\$ 38,922 \\
\$ 52,729\end{array}$ & $\begin{array}{l}-\$ 177 \\
-\$ 108 \\
-\$ 56 \\
-\$ 57\end{array}$ & $\begin{array}{l}-0.3 \% \\
-0.2 \% \\
-0.1 \% \\
-0.1 \%\end{array}$ & $\begin{array}{l}\$ 60,059 \\
\$ 44,944 \\
\$ 39,175 \\
\$ 53,260\end{array}$ & $\begin{array}{l}\$ 884 \\
\$ 188 \\
\$ 197 \\
\$ 473\end{array}$ & $\begin{array}{l}1.5 \% \\
0.4 \% \\
0.5 \% \\
0.9 \%\end{array}$ & $\begin{array}{l}\$ 59,380 \\
\$ 44,973 \\
\$ 39,148 \\
\$ 52,925\end{array}$ & $\begin{array}{l}\$ 205 \\
\$ 217 \\
\$ 170 \\
\$ 139\end{array}$ & $\begin{array}{l}0.3 \% \\
0.5 \% \\
0.4 \% \\
0.3 \%\end{array}$ & $\begin{array}{l}\$ 59,044 \\
\$ 44,617 \\
\$ 38,877 \\
\$ 52,724\end{array}$ & $\begin{array}{l}-\$ 131 \\
-\$ 138 \\
-\$ 101 \\
-\$ 62\end{array}$ & $\begin{array}{l}-0.2 \% \\
-0.3 \% \\
-0.3 \% \\
-0.1 \%\end{array}$ \\
\hline $\begin{array}{l}\text { Education } \\
\text { High school dropout } \\
\text { High school graduate } \\
\text { College graduate }\end{array}$ & $\begin{array}{l}\$ 28,415 \\
\$ 46,502 \\
\$ 81,445\end{array}$ & $\begin{array}{l}\$ 28,401 \\
\$ 46,432 \\
\$ 81,096\end{array}$ & $\begin{array}{l}-\$ 13 \\
-\$ 70 \\
-\$ 349\end{array}$ & $\begin{array}{l}0.0 \% \\
-0.2 \% \\
-0.4 \%\end{array}$ & $\begin{array}{l}\$ 28,534 \\
\$ 46,840 \\
\$ 83,068\end{array}$ & $\begin{array}{c}\$ 120 \\
\$ 338 \\
\$ 1,623\end{array}$ & $\begin{array}{l}0.4 \% \\
0.7 \% \\
2.0 \%\end{array}$ & $\begin{array}{l}\$ 28,526 \\
\$ 46,730 \\
\$ 81,615\end{array}$ & $\begin{array}{l}\$ 111 \\
\$ 228 \\
\$ 170\end{array}$ & $\begin{array}{l}0.4 \% \\
0.5 \% \\
0.2 \%\end{array}$ & $\begin{array}{l}\$ 28,327 \\
\$ 46,362 \\
\$ 81,344\end{array}$ & $\begin{array}{c}-\$ 88 \\
-\$ 140 \\
-\$ 100\end{array}$ & $\begin{array}{l}-0.3 \% \\
-0.3 \% \\
-0.1 \%\end{array}$ \\
\hline $\begin{array}{l}\text { Lifetime Earnings } \\
\text { 1st Quintile } \\
\text { 2nd Quintile } \\
\text { 3rd Quintile } \\
\text { 4th Quintile } \\
\text { 5th Quintile }\end{array}$ & $\begin{array}{c}\$ 22,736 \\
\$ 32,304 \\
\$ 44,695 \\
\$ 62,224 \\
\$ 109,112\end{array}$ & $\begin{array}{c}\$ 22,736 \\
\$ 32,306 \\
\$ 44,688 \\
\$ 62,136 \\
\$ 108,489\end{array}$ & $\begin{array}{c}\$ 0 \\
\$ 2 \\
-\$ 7 \\
-\$ 88 \\
-\$ 623\end{array}$ & $\begin{array}{c}0.0 \% \\
0.0 \% \\
0.0 \% \\
-0.1 \% \\
-0.6 \%\end{array}$ & $\begin{array}{c}\$ 22,778 \\
\$ 32,383 \\
\$ 44,871 \\
\$ 62,712 \\
\$ 111,728\end{array}$ & $\begin{array}{c}\$ 42 \\
\$ 78 \\
\$ 176 \\
\$ 488 \\
\$ 2,615\end{array}$ & $\begin{array}{l}0.2 \% \\
0.2 \% \\
0.4 \% \\
0.8 \% \\
2.4 \%\end{array}$ & $\begin{array}{c}\$ 22,826 \\
\$ 32,552 \\
\$ 44,974 \\
\$ 62,471 \\
\$ 109,232\end{array}$ & $\begin{array}{l}\$ 90 \\
\$ 247 \\
\$ 279 \\
\$ 246 \\
\$ 120\end{array}$ & $\begin{array}{l}0.4 \% \\
0.8 \% \\
0.6 \% \\
0.4 \% \\
0.1 \%\end{array}$ & $\begin{array}{l}\$ 22,654 \\
\$ 32,135 \\
\$ 44,523 \\
\$ 62,104 \\
\$ 109,046\end{array}$ & $\begin{array}{c}-\$ 82 \\
-\$ 169 \\
-\$ 173 \\
-\$ 120 \\
-\$ 66\end{array}$ & $\begin{array}{l}-0.4 \% \\
-0.5 \% \\
-0.4 \% \\
-0.2 \% \\
-0.1 \%\end{array}$ \\
\hline $\begin{array}{l}\text { Household Income } \\
\text { 1st Quintile } \\
\text { 2nd Quintile } \\
\text { 3rd Quintile } \\
\text { 4th Quintile } \\
\text { 5th Quintile }\end{array}$ & $\begin{array}{l}\$ 20,834 \\
\$ 29,138 \\
\$ 41,448 \\
\$ 62,109 \\
\$ 117,547\end{array}$ & $\begin{array}{l}\$ 20,834 \\
\$ 29,139 \\
\$ 41,442 \\
\$ 62,084 \\
\$ 116,861\end{array}$ & $\begin{array}{l}\$ 0 \\
\$ 1 \\
-\$ 6 \\
-\$ 26 \\
-\$ 686\end{array}$ & $\begin{array}{c}0.0 \% \\
0.0 \% \\
0.0 \% \\
0.0 \% \\
-0.6 \%\end{array}$ & $\begin{array}{c}\$ 20,848 \\
\$ 29,214 \\
\$ 41,616 \\
\$ 62,535 \\
\$ 120,261\end{array}$ & $\begin{array}{c}\$ 15 \\
\$ 76 \\
\$ 169 \\
\$ 426 \\
\$ 2,714\end{array}$ & $\begin{array}{l}0.1 \% \\
0.3 \% \\
0.4 \% \\
0.7 \% \\
2.3 \%\end{array}$ & $\begin{array}{c}\$ 20,884 \\
\$ 29,390 \\
\$ 41,886 \\
\$ 62,334 \\
\$ 117,564\end{array}$ & $\begin{array}{c}\$ 50 \\
\$ 252 \\
\$ 438 \\
\$ 225 \\
\$ 17\end{array}$ & $\begin{array}{l}0.2 \% \\
0.9 \% \\
1.1 \% \\
0.4 \% \\
0.0 \%\end{array}$ & $\begin{array}{c}\$ 20,771 \\
\$ 28,885 \\
\$ 41,231 \\
\$ 62,038 \\
\$ 117,540\end{array}$ & $\begin{array}{c}-\$ 63 \\
-\$ 253 \\
-\$ 216 \\
-\$ 71 \\
-\$ 8\end{array}$ & $\begin{array}{c}-0.3 \% \\
-0.9 \% \\
-0.5 \% \\
-0.1 \% \\
0.0 \%\end{array}$ \\
\hline
\end{tabular}

Notes: Sample includes adults born 1960 to 1964. Dollar amounts are expressed in 2005 dollars.

Source: Authors' tabulations of DYNASIM3 (see text for details). 
Table 4a. The Change in Per Capita After-Tax Household Income Among Adults Age 67 Who Win or Lose under Alternative Tax Scenarios 1946-1950 Birth Cohorts

\begin{tabular}{|c|c|c|c|c|c|c|c|c|c|c|c|c|}
\hline & \multicolumn{6}{|c|}{$\begin{array}{l}\text { Reduce Capital Gains/Dividends Tax } \\
\text { Rate } \\
\end{array}$} & \multicolumn{3}{|c|}{ Index Social Security Thresholds } & \multicolumn{3}{|c|}{ Eliminate Social Security Thresholds } \\
\hline & \% Lose & $\begin{array}{c}\text { Change in } \\
\text { Level } \\
\text { Among } \\
\text { Losers } \\
\end{array}$ & $\begin{array}{c}\text { \% Change } \\
\text { Among } \\
\text { Losers } \\
\end{array}$ & $\%$ Win & $\begin{array}{c}\text { Change in } \\
\text { Level } \\
\text { Among } \\
\text { Winners } \\
\end{array}$ & $\begin{array}{l}\text { \% Change } \\
\text { Among } \\
\text { Winners } \\
\end{array}$ & $\%$ Win & $\begin{array}{c}\text { Change in } \\
\text { Level } \\
\text { Among } \\
\text { Winners } \\
\end{array}$ & $\begin{array}{c}\text { \% Change } \\
\text { Among } \\
\text { Winners } \\
\end{array}$ & \% Lose & $\begin{array}{c}\text { Change in } \\
\text { Level } \\
\text { Among } \\
\text { Losers } \\
\end{array}$ & $\begin{array}{c}\text { \% Change } \\
\text { Among } \\
\text { Losers } \\
\end{array}$ \\
\hline Total & $2.9 \%$ & $-\$ 569$ & $-0.5 \%$ & $40.4 \%$ & $\$ 896$ & $1.5 \%$ & $21.5 \%$ & $\$ 380$ & $1.1 \%$ & $30.5 \%$ & $-\$ 762$ & $-2.4 \%$ \\
\hline $\begin{array}{l}\text { Sex } \\
\text { Female } \\
\text { Male }\end{array}$ & $\begin{array}{l}2.3 \% \\
3.5 \%\end{array}$ & $\begin{array}{l}-\$ 394 \\
-\$ 708\end{array}$ & $\begin{array}{l}-0.4 \% \\
-0.6 \%\end{array}$ & $\begin{array}{l}37.1 \% \\
44.2 \%\end{array}$ & $\begin{array}{l}\$ 668 \\
\$ 1,123\end{array}$ & $\begin{array}{l}1.1 \% \\
1.8 \%\end{array}$ & $\begin{array}{l}20.7 \% \\
22.5 \%\end{array}$ & $\begin{array}{l}\$ 403 \\
\$ 356\end{array}$ & $\begin{array}{l}1.1 \% \\
1.0 \%\end{array}$ & $\begin{array}{l}30.5 \% \\
30.5 \%\end{array}$ & $\begin{array}{l}-\$ 773 \\
-\$ 750\end{array}$ & $\begin{array}{l}-2.4 \% \\
-2.4 \%\end{array}$ \\
\hline $\begin{array}{l}\text { Marital Status } \\
\text { Married } \\
\text { Widowed } \\
\text { Divorced } \\
\text { Never married }\end{array}$ & $\begin{array}{l}3.6 \% \\
1.7 \% \\
1.8 \% \\
1.3 \%\end{array}$ & $\begin{array}{c}-\$ 475 \\
-\$ 1,474 \\
-\$ 460 \\
-\$ 1,153\end{array}$ & $\begin{array}{l}-0.5 \% \\
-0.9 \% \\
-0.4 \% \\
-0.7 \%\end{array}$ & $\begin{array}{l}48.7 \% \\
23.8 \% \\
27.2 \% \\
24.6 \%\end{array}$ & $\begin{array}{l}\$ 851 \\
\$ 1,687 \\
\$ 475 \\
\$ 1,383\end{array}$ & $\begin{array}{l}1.5 \% \\
2.0 \% \\
0.7 \% \\
1.6 \%\end{array}$ & $\begin{array}{l}24.1 \% \\
16.2 \% \\
17.9 \% \\
15.8 \%\end{array}$ & $\begin{array}{l}\$ 344 \\
\$ 471 \\
\$ 492 \\
\$ 423\end{array}$ & $\begin{array}{l}1.1 \% \\
0.9 \% \\
1.1 \% \\
0.8 \%\end{array}$ & $\begin{array}{l}32.0 \% \\
28.0 \% \\
27.6 \% \\
27.9 \%\end{array}$ & $\begin{array}{c}-\$ 700 \\
-\$ 1,051 \\
-\$ 829 \\
-\$ 741\end{array}$ & $\begin{array}{l}-2.6 \% \\
-2.5 \% \\
-2.1 \% \\
-1.6 \%\end{array}$ \\
\hline $\begin{array}{l}\text { Race/Ethnicity } \\
\text { White, non-Hispanic } \\
\text { Black, non-Hispanic } \\
\text { Hispanic } \\
\text { Asian/Native American }\end{array}$ & $\begin{array}{l}3.6 \% \\
0.0 \% \\
0.7 \% \\
2.6 \%\end{array}$ & $\begin{array}{c}-\$ 522 \\
\$ 0 \\
-\$ 501 \\
-\$ 1,427\end{array}$ & $\begin{array}{l}-0.5 \% \\
-0.6 \% \\
-1.0 \%\end{array}$ & $\begin{array}{l}46.8 \% \\
18.3 \% \\
18.7 \% \\
30.4 \%\end{array}$ & $\begin{array}{l}\$ 974 \\
\$ 242 \\
\$ 268 \\
\$ 657\end{array}$ & $\begin{array}{l}1.5 \% \\
0.5 \% \\
0.6 \% \\
1.0 \%\end{array}$ & $\begin{array}{l}22.6 \% \\
24.3 \% \\
16.7 \% \\
13.0 \%\end{array}$ & $\begin{array}{l}\$ 384 \\
\$ 385 \\
\$ 339 \\
\$ 377\end{array}$ & $\begin{array}{l}1.1 \% \\
1.1 \% \\
1.1 \% \\
0.9 \%\end{array}$ & $\begin{array}{l}31.5 \% \\
37.1 \% \\
23.9 \% \\
19.9 \%\end{array}$ & $\begin{array}{l}-\$ 768 \\
-\$ 815 \\
-\$ 652 \\
-\$ 745\end{array}$ & $\begin{array}{l}-2.4 \% \\
-2.6 \% \\
-2.2 \% \\
-2.2 \%\end{array}$ \\
\hline $\begin{array}{l}\text { Education } \\
\text { High school dropout } \\
\text { High school graduate } \\
\text { College graduate }\end{array}$ & $\begin{array}{l}0.3 \% \\
1.6 \% \\
6.5 \%\end{array}$ & $\begin{array}{l}-\$ 600 \\
-\$ 490 \\
-\$ 606\end{array}$ & $\begin{array}{l}-0.8 \% \\
-0.5 \% \\
-0.5 \%\end{array}$ & $\begin{array}{l}12.5 \% \\
34.6 \% \\
63.8 \%\end{array}$ & $\begin{array}{c}\$ 279 \\
\$ 452 \\
\$ 1,410\end{array}$ & $\begin{array}{l}0.7 \% \\
0.9 \% \\
1.9 \%\end{array}$ & $\begin{array}{l}12.8 \% \\
24.1 \% \\
20.4 \%\end{array}$ & $\begin{array}{l}\$ 304 \\
\$ 374 \\
\$ 417\end{array}$ & $\begin{array}{l}1.0 \% \\
1.1 \% \\
1.0 \%\end{array}$ & $\begin{array}{l}22.1 \% \\
36.1 \% \\
23.6 \%\end{array}$ & $\begin{array}{l}-\$ 676 \\
-\$ 765 \\
-\$ 790\end{array}$ & $\begin{array}{l}-2.5 \% \\
-2.5 \% \\
-2.1 \%\end{array}$ \\
\hline $\begin{array}{l}\text { Lifetime Earnings } \\
\text { 1st Quintile } \\
\text { 2nd Quintile } \\
\text { 3rd Quintile } \\
\text { 4th Quintile } \\
\text { 5th Quintile }\end{array}$ & $\begin{array}{c}0.0 \% \\
0.1 \% \\
0.7 \% \\
3.1 \% \\
10.6 \%\end{array}$ & $\begin{array}{c}\$ 0 \\
-\$ 21 \\
-\$ 420 \\
-\$ 387 \\
-\$ 636\end{array}$ & $\begin{array}{c}0.0 \% \\
-0.6 \% \\
-0.4 \% \\
-0.5 \%\end{array}$ & $\begin{array}{c}6.5 \% \\
17.0 \% \\
39.2 \% \\
60.7 \% \\
78.5 \%\end{array}$ & $\begin{array}{l}\$ 228 \\
\$ 191 \\
\$ 254 \\
\$ 565 \\
\$ 1,680\end{array}$ & $\begin{array}{l}0.7 \% \\
0.6 \% \\
0.6 \% \\
1.0 \% \\
2.0 \%\end{array}$ & $\begin{array}{c}5.7 \% \\
21.8 \% \\
34.6 \% \\
29.5 \% \\
15.9 \%\end{array}$ & $\begin{array}{l}\$ 291 \\
\$ 288 \\
\$ 350 \\
\$ 435 \\
\$ 503\end{array}$ & $\begin{array}{l}1.2 \% \\
1.0 \% \\
1.1 \% \\
1.1 \% \\
1.0 \%\end{array}$ & $\begin{array}{l}20.2 \% \\
39.2 \% \\
45.0 \% \\
33.2 \% \\
15.0 \%\end{array}$ & $\begin{array}{l}-\$ 593 \\
-\$ 734 \\
-\$ 767 \\
-\$ 825 \\
-\$ 916\end{array}$ & $\begin{array}{l}-2.6 \% \\
-2.8 \% \\
-2.5 \% \\
-2.2 \% \\
-1.9 \%\end{array}$ \\
\hline $\begin{array}{l}\text { Household Income } \\
\text { 1st Quintile } \\
\text { 2nd Quintile } \\
\text { 3rd Quintile } \\
\text { 4th Quintile } \\
\text { 5th Quintile }\end{array}$ & $\begin{array}{c}0.0 \% \\
0.2 \% \\
0.5 \% \\
2.3 \% \\
11.3 \%\end{array}$ & $\begin{array}{c}\$ 0 \\
-\$ 147 \\
-\$ 147 \\
-\$ 288 \\
-\$ 655\end{array}$ & $\begin{array}{l}\cdot \\
-0.3 \% \\
-0.3 \% \\
-0.4 \% \\
-0.5 \%\end{array}$ & $\begin{array}{c}1.0 \% \\
13.0 \% \\
36.8 \% \\
66.6 \% \\
84.5 \%\end{array}$ & $\begin{array}{l}\$ 108 \\
\$ 170 \\
\$ 160 \\
\$ 248 \\
\$ 1,848\end{array}$ & $\begin{array}{l}0.6 \% \\
0.5 \% \\
0.4 \% \\
0.5 \% \\
2.1 \%\end{array}$ & $\begin{array}{c}0.3 \% \\
17.5 \% \\
49.3 \% \\
35.7 \% \\
4.8 \%\end{array}$ & $\begin{array}{l}\$ 95 \\
\$ 302 \\
\$ 378 \\
\$ 433 \\
\$ 316\end{array}$ & $\begin{array}{l}0.3 \% \\
1.0 \% \\
1.2 \% \\
1.1 \% \\
0.5 \%\end{array}$ & $\begin{array}{c}10.8 \% \\
46.4 \% \\
58.1 \% \\
32.6 \% \\
4.6 \%\end{array}$ & $\begin{array}{l}-\$ 504 \\
-\$ 828 \\
-\$ 866 \\
-\$ 626 \\
-\$ 365\end{array}$ & $\begin{array}{l}-2.1 \% \\
-3.2 \% \\
-2.8 \% \\
-1.6 \% \\
-0.5 \%\end{array}$ \\
\hline Unweighted Obs. & & 188 & & & 2,635 & & & 1,404 & & & 1,991 & \\
\hline
\end{tabular}

Notes: Sample includes adults born 1946 to 1950 whose after-tax household incomes increase or decrease by at least $\$ 10$ under the respective simulation. Dollar amounts are expressed in 2005 dollars.

Source: Authors' tabulations of DYNASIM3 (see text for details). 
Table 4b. The Change in Per Capita After-Tax Household Income Among Adults Age 67 Who Win or Lose under Alternative Tax Scenarios 1960-1964 Birth Cohorts

\begin{tabular}{|c|c|c|c|c|c|c|c|c|c|c|c|c|}
\hline & \multicolumn{9}{|c|}{ Reduce Capital Gains/Dividends Tax } & \multirow{2}{*}{\multicolumn{3}{|c|}{ Eliminate Social Security Threshold }} \\
\hline & \multicolumn{3}{|c|}{ Reduce 401(k) Contribution Limit } & \multicolumn{3}{|c|}{ Rate } & \multicolumn{3}{|c|}{ Index Social Security Thresholds } & & & \\
\hline & $\%$ Lose & $\begin{array}{c}\text { Change in } \\
\text { Level } \\
\text { Among } \\
\text { Losers } \\
\end{array}$ & $\begin{array}{c}\text { \% Change } \\
\text { Among } \\
\text { Losers } \\
\end{array}$ & $\%$ Win & $\begin{array}{c}\text { Change in } \\
\text { Level } \\
\text { Among } \\
\text { Winners } \\
\end{array}$ & $\begin{array}{l}\text { \% Change } \\
\text { Among } \\
\text { Winners } \\
\end{array}$ & $\%$ Win & $\begin{array}{c}\text { Change in } \\
\text { Level } \\
\text { Among } \\
\text { Winners } \\
\end{array}$ & $\begin{array}{c}\text { \% Change } \\
\text { Among } \\
\text { Winners } \\
\end{array}$ & $\%$ Lose & $\begin{array}{c}\text { Change in } \\
\text { Level } \\
\text { Among } \\
\text { Losers } \\
\end{array}$ & $\begin{array}{c}\text { \% Change } \\
\text { Among } \\
\text { Losers } \\
\end{array}$ \\
\hline Total & $4.1 \%$ & $-\$ 3,768$ & $-1.9 \%$ & $57.6 \%$ & $\$ 1,205$ & $1.6 \%$ & $28.9 \%$ & $\$ 681$ & $1.5 \%$ & $22.7 \%$ & $-\$ 539$ & $-1.4 \%$ \\
\hline $\begin{array}{l}\text { Sex } \\
\text { Female } \\
\text { Male }\end{array}$ & $\begin{array}{l}4.0 \% \\
4.1 \%\end{array}$ & $\begin{array}{l}-\$ 3,598 \\
-\$ 3,957\end{array}$ & $\begin{array}{l}-1.9 \% \\
-2.0 \%\end{array}$ & $\begin{array}{l}55.5 \% \\
60.0 \%\end{array}$ & $\begin{array}{l}\$ 1,300 \\
\$ 1,104\end{array}$ & $\begin{array}{l}1.7 \% \\
1.6 \%\end{array}$ & $\begin{array}{l}28.3 \% \\
29.5 \%\end{array}$ & $\begin{array}{l}\$ 715 \\
\$ 643\end{array}$ & $\begin{array}{l}1.6 \% \\
1.5 \%\end{array}$ & $\begin{array}{l}22.6 \% \\
22.8 \%\end{array}$ & $\begin{array}{l}-\$ 561 \\
-\$ 514\end{array}$ & $\begin{array}{l}-1.4 \% \\
-1.3 \%\end{array}$ \\
\hline $\begin{array}{l}\text { Marital Status } \\
\text { Married } \\
\text { Widowed } \\
\text { Divorced } \\
\text { Never married }\end{array}$ & $\begin{array}{l}4.8 \% \\
4.5 \% \\
1.9 \% \\
2.8 \%\end{array}$ & $\begin{array}{c}-\$ 2,344 \\
-\$ 6,386 \\
-\$ 10,329 \\
-\$ 6,134\end{array}$ & $\begin{array}{l}-1.5 \% \\
-2.3 \% \\
-3.5 \% \\
-1.9 \%\end{array}$ & $\begin{array}{l}63.5 \% \\
51.5 \% \\
50.4 \% \\
42.9 \%\end{array}$ & $\begin{array}{c}\$ 980 \\
\$ 1,855 \\
\$ 1,396 \\
\$ 1,845\end{array}$ & $\begin{array}{l}1.5 \% \\
1.8 \% \\
1.7 \% \\
1.8 \%\end{array}$ & $\begin{array}{l}30.4 \% \\
28.2 \% \\
24.6 \% \\
27.5 \%\end{array}$ & $\begin{array}{l}\$ 570 \\
\$ 887 \\
\$ 895 \\
\$ 843\end{array}$ & $\begin{array}{l}1.5 \% \\
1.5 \% \\
1.9 \% \\
1.4 \%\end{array}$ & $\begin{array}{l}22.7 \% \\
25.2 \% \\
20.0 \% \\
24.3 \%\end{array}$ & $\begin{array}{l}-\$ 484 \\
-\$ 691 \\
-\$ 640 \\
-\$ 536\end{array}$ & $\begin{array}{l}-1.5 \% \\
-1.2 \% \\
-1.6 \% \\
-1.0 \%\end{array}$ \\
\hline $\begin{array}{l}\text { Race/Ethnicity } \\
\text { White, non-Hispanic } \\
\text { Black, non-Hispanic } \\
\text { Hispanic } \\
\text { Asian/Native American }\end{array}$ & $\begin{array}{l}5.2 \% \\
1.2 \% \\
1.8 \% \\
2.0 \%\end{array}$ & $\begin{array}{l}-\$ 3,672 \\
-\$ 8,890 \\
-\$ 3,153 \\
-\$ 2,807\end{array}$ & $\begin{array}{l}-1.9 \% \\
-3.4 \% \\
-2.0 \% \\
-1.4 \%\end{array}$ & $\begin{array}{l}65.3 \% \\
44.8 \% \\
36.7 \% \\
47.3 \%\end{array}$ & $\begin{array}{l}\$ 1,384 \\
\$ 428 \\
\$ 548 \\
\$ 1,005\end{array}$ & $\begin{array}{l}1.8 \% \\
0.6 \% \\
0.9 \% \\
1.4 \%\end{array}$ & $\begin{array}{l}29.7 \% \\
33.2 \% \\
26.9 \% \\
19.6 \%\end{array}$ & $\begin{array}{l}\$ 693 \\
\$ 656 \\
\$ 634 \\
\$ 708\end{array}$ & $\begin{array}{l}1.6 \% \\
1.4 \% \\
1.7 \% \\
1.4 \%\end{array}$ & $\begin{array}{l}23.7 \% \\
27.0 \% \\
19.9 \% \\
13.6 \%\end{array}$ & $\begin{array}{l}-\$ 554 \\
-\$ 513 \\
-\$ 509 \\
-\$ 459\end{array}$ & $\begin{array}{l}-1.4 \% \\
-1.1 \% \\
-1.5 \% \\
-1.1 \%\end{array}$ \\
\hline $\begin{array}{l}\text { Education } \\
\text { High school dropout } \\
\text { High school graduate } \\
\text { College graduate }\end{array}$ & $\begin{array}{l}0.5 \% \\
2.4 \% \\
9.1 \%\end{array}$ & $\begin{array}{l}-\$ 2,809 \\
-\$ 3,262 \\
-\$ 4,055\end{array}$ & $\begin{array}{l}-2.2 \% \\
-1.7 \% \\
-2.1 \%\end{array}$ & $\begin{array}{l}23.9 \% \\
56.0 \% \\
76.1 \%\end{array}$ & $\begin{array}{l}\$ 503 \\
\$ 613 \\
\$ 2,184\end{array}$ & $\begin{array}{l}1.1 \% \\
1.0 \% \\
2.3 \%\end{array}$ & $\begin{array}{l}20.3 \% \\
33.3 \% \\
23.9 \%\end{array}$ & $\begin{array}{l}\$ 550 \\
\$ 688 \\
\$ 712\end{array}$ & $\begin{array}{l}1.7 \% \\
1.6 \% \\
1.3 \%\end{array}$ & $\begin{array}{l}18.3 \% \\
26.1 \% \\
18.0 \%\end{array}$ & $\begin{array}{l}-\$ 488 \\
-\$ 541 \\
-\$ 558\end{array}$ & $\begin{array}{l}-1.5 \% \\
-1.5 \% \\
-1.1 \%\end{array}$ \\
\hline $\begin{array}{l}\text { Lifetime Earnings } \\
\text { 1st Quintile } \\
\text { 2nd Quintile } \\
\text { 3rd Quintile } \\
\text { 4th Quintile } \\
\text { 5th Quintile }\end{array}$ & $\begin{array}{c}0.0 \% \\
0.2 \% \\
0.9 \% \\
4.4 \% \\
14.8 \%\end{array}$ & $\begin{array}{c}\$ 0 \\
-\$ 134 \\
-\$ 733 \\
-\$ 2,152 \\
-\$ 4,489\end{array}$ & $\begin{array}{l}-0.2 \% \\
-0.6 \% \\
-1.3 \% \\
-2.2 \%\end{array}$ & $\begin{array}{l}12.9 \% \\
44.0 \% \\
64.0 \% \\
78.7 \% \\
88.2 \%\end{array}$ & $\begin{array}{l}\$ 323 \\
\$ 180 \\
\$ 278 \\
\$ 630 \\
\$ 3,032\end{array}$ & $\begin{array}{l}0.9 \% \\
0.4 \% \\
0.5 \% \\
0.9 \% \\
2.5 \%\end{array}$ & $\begin{array}{l}18.2 \% \\
39.4 \% \\
40.7 \% \\
31.8 \% \\
14.3 \%\end{array}$ & $\begin{array}{l}\$ 492 \\
\$ 629 \\
\$ 685 \\
\$ 777 \\
\$ 840\end{array}$ & $\begin{array}{l}1.7 \% \\
1.7 \% \\
1.6 \% \\
1.5 \% \\
1.2 \%\end{array}$ & $\begin{array}{l}19.6 \% \\
33.0 \% \\
30.4 \% \\
20.4 \% \\
10.4 \%\end{array}$ & $\begin{array}{l}-\$ 423 \\
-\$ 514 \\
-\$ 569 \\
-\$ 593 \\
-\$ 643\end{array}$ & $\begin{array}{l}-1.6 \% \\
-1.6 \% \\
-1.4 \% \\
-1.2 \% \\
-1.0 \%\end{array}$ \\
\hline $\begin{array}{l}\text { Household Income } \\
\text { 1st Quintile } \\
\text { 2nd Quintile } \\
\text { 3rd Quintile } \\
\text { 4th Quintile } \\
\text { 5th Quintile }\end{array}$ & $\begin{array}{c}0.0 \% \\
0.1 \% \\
0.9 \% \\
3.8 \% \\
15.5 \%\end{array}$ & $\begin{array}{c}\$ 0 \\
-\$ 1,152 \\
-\$ 681 \\
-\$ 1,135 \\
-\$ 4,620\end{array}$ & $\begin{array}{c}\cdot \\
-2.3 \% \\
-0.8 \% \\
-0.9 \% \\
-2.1 \%\end{array}$ & $\begin{array}{l}11.1 \% \\
38.8 \% \\
66.3 \% \\
82.5 \% \\
89.2 \%\end{array}$ & $\begin{array}{l}\$ 134 \\
\$ 201 \\
\$ 261 \\
\$ 528 \\
\$ 3,104\end{array}$ & $\begin{array}{l}0.4 \% \\
0.5 \% \\
0.6 \% \\
0.8 \% \\
2.5 \%\end{array}$ & $\begin{array}{c}8.4 \% \\
37.9 \% \\
54.7 \% \\
35.9 \% \\
7.4 \%\end{array}$ & $\begin{array}{l}\$ 600 \\
\$ 667 \\
\$ 801 \\
\$ 626 \\
\$ 225\end{array}$ & $\begin{array}{l}1.8 \% \\
2.0 \% \\
2.1 \% \\
1.2 \% \\
0.2 \%\end{array}$ & $\begin{array}{c}13.2 \% \\
39.8 \% \\
37.0 \% \\
19.5 \% \\
4.3 \%\end{array}$ & $\begin{array}{l}-\$ 481 \\
-\$ 638 \\
-\$ 586 \\
-\$ 367 \\
-\$ 177\end{array}$ & $\begin{array}{l}-1.7 \% \\
-2.2 \% \\
-1.6 \% \\
-0.6 \% \\
-0.1 \%\end{array}$ \\
\hline Unweighted Obs. & & 323 & & & 4,581 & & & 2,298 & & & 1,809 & \\
\hline
\end{tabular}

Notes: Sample includes adults born 1960 to 1964 whose after-tax household incomes increase or decrease by at least $\$ 10$ under the simulation. Dollar amounts are expressed in 2005 dollars. Source: Authors' tabulations of DYNASIM3 (see text for details). 
Table 5a. Percent of Aggregate Income Going to Adults Age 67 Under Alternative Tax Scenarios 1946-1950 Birth Cohorts

\begin{tabular}{|c|c|c|c|c|c|c|}
\hline & \multicolumn{2}{|c|}{ Baseline } & \multicolumn{4}{|c|}{ Share of Additional/Lost Income from Simulation } \\
\hline & $\begin{array}{c}\text { Percent of } \\
\text { Sample } \\
\end{array}$ & $\begin{array}{c}\text { Share of } \\
\text { Baseline } \\
\text { Income } \\
\end{array}$ & $\begin{array}{c}\text { Reduce 401(k) } \\
\text { Contribution } \\
\text { Limits } \\
\end{array}$ & $\begin{array}{c}\text { Reduce Capital } \\
\text { Gains/Dividends } \\
\text { Tax Rate } \\
\end{array}$ & $\begin{array}{c}\text { Index Social } \\
\text { Security } \\
\text { Thresholds } \\
\end{array}$ & $\begin{array}{c}\text { Eliminate Social } \\
\text { Security } \\
\text { Thresholds } \\
\end{array}$ \\
\hline Total & 100.0 & 100.0 & 100.0 & 100.0 & 100.0 & 100.0 \\
\hline $\begin{array}{l}\text { Sex } \\
\text { Female } \\
\text { Male }\end{array}$ & $\begin{array}{l}54.2 \\
45.8\end{array}$ & $\begin{array}{l}53.8 \\
46.2\end{array}$ & $\begin{array}{l}36.2 \\
63.8\end{array}$ & $\begin{array}{l}37.2 \\
62.8\end{array}$ & $\begin{array}{l}55.2 \\
44.8\end{array}$ & $\begin{array}{l}54.9 \\
45.1\end{array}$ \\
\hline $\begin{array}{l}\text { Marital Status } \\
\text { Married } \\
\text { Widowed } \\
\text { Divorced } \\
\text { Never married }\end{array}$ & $\begin{array}{c}64.1 \\
12.7 \\
16.1 \\
7.1\end{array}$ & $\begin{array}{c}61.8 \\
15.3 \\
15.4 \\
7.4\end{array}$ & $\begin{array}{c}66.1 \\
26.3 \\
4.2 \\
3.3\end{array}$ & $\begin{array}{c}73.6 \\
14.1 \\
5.7 \\
6.6\end{array}$ & $\begin{array}{c}65.0 \\
11.8 \\
17.4 \\
5.8\end{array}$ & $\begin{array}{c}61.8 \\
16.1 \\
15.9 \\
6.3\end{array}$ \\
\hline $\begin{array}{l}\text { Race/Ethnicity } \\
\text { White, non-Hisp anic } \\
\text { Black, non-Hispanic } \\
\text { Hispanic } \\
\text { Asian/Native American }\end{array}$ & $\begin{array}{c}74.7 \\
8.6 \\
10.7 \\
6.0\end{array}$ & $\begin{array}{c}81.0 \\
6.1 \\
7.2 \\
5.7\end{array}$ & $\begin{array}{c}78.5 \\
0.0 \\
3.2 \\
18.2\end{array}$ & $\begin{array}{c}94.2 \\
1.1 \\
1.5 \\
3.3\end{array}$ & $\begin{array}{l}79.1 \\
9.9 \\
7.4 \\
3.6\end{array}$ & $\begin{array}{c}77.8 \\
11.2 \\
7.2 \\
3.8\end{array}$ \\
\hline $\begin{array}{l}\text { Education } \\
\text { High school dropout } \\
\text { High school graduate } \\
\text { College graduate }\end{array}$ & $\begin{array}{l}13.3 \\
57.0 \\
29.8\end{array}$ & $\begin{array}{c}7.4 \\
49.3 \\
43.3\end{array}$ & $\begin{array}{c}2.3 \\
35.9 \\
61.8\end{array}$ & $\begin{array}{c}1.3 \\
24.6 \\
74.1\end{array}$ & $\begin{array}{c}6.3 \\
62.8 \\
30.9\end{array}$ & $\begin{array}{c}8.5 \\
67.6 \\
23.9\end{array}$ \\
\hline $\begin{array}{l}\text { Lifetime Earnings } \\
\text { 1st Quintile } \\
\text { 2nd Quintile } \\
\text { 3rd Quintile } \\
\text { 4th Quintile } \\
\text { 5th Quintile }\end{array}$ & $\begin{array}{l}20.0 \\
20.0 \\
20.0 \\
20.0 \\
20.0\end{array}$ & $\begin{array}{c}9.4 \\
12.4 \\
17.0 \\
23.7 \\
37.5\end{array}$ & $\begin{array}{c}0.0 \\
0.0 \\
4.8 \\
19.0 \\
76.2\end{array}$ & $\begin{array}{c}0.8 \\
1.8 \\
5.5 \\
18.9 \\
72.9\end{array}$ & $\begin{array}{c}4.1 \\
15.4 \\
29.6 \\
31.4 \\
19.6\end{array}$ & $\begin{array}{l}10.3 \\
24.7 \\
29.7 \\
23.5 \\
11.8\end{array}$ \\
\hline $\begin{array}{l}\text { Household Income } \\
\text { 1st Quintile } \\
\text { 2nd Quintile } \\
\text { 3rd Quintile } \\
\text { 4th Quintile } \\
\text { 5th Quintile }\end{array}$ & $\begin{array}{l}20.0 \\
20.0 \\
20.0 \\
20.0 \\
20.0\end{array}$ & $\begin{array}{c}8.7 \\
11.9 \\
16.2 \\
22.4 \\
40.8\end{array}$ & $\begin{array}{c}0.0 \\
0.5 \\
1.3 \\
10.2 \\
87.9\end{array}$ & $\begin{array}{c}0.1 \\
1.2 \\
3.2 \\
9.1 \\
86.4\end{array}$ & $\begin{array}{c}0.1 \\
13.0 \\
45.5 \\
37.8 \\
3.7\end{array}$ & $\begin{array}{c}4.7 \\
33.1 \\
43.3 \\
17.6 \\
1.4\end{array}$ \\
\hline Unweighted Obs. & 6,526 & 6,526 & 6,526 & 6,526 & 6,526 & 6,526 \\
\hline
\end{tabular}

Notes: Sample includes adults born 1946 to 1950.

Source: Authors' tabulations of DYNASIM3 (see text for details). 
Table 5b. Percent of Aggregate Income Going to Adults Age 67 Under Alternative Tax Scenarios 1960-1964 Birth Cohorts

\begin{tabular}{|c|c|c|c|c|c|c|}
\hline & \multicolumn{2}{|c|}{ Baseline } & \multicolumn{4}{|c|}{ Share of Additional/Lost Income from Simulation } \\
\hline & $\begin{array}{c}\text { Percent of } \\
\text { Sample }\end{array}$ & $\begin{array}{c}\text { Share of } \\
\text { Baseline } \\
\text { Income }\end{array}$ & $\begin{array}{c}\text { Reduce 401(k) } \\
\text { Contribution } \\
\text { Limits }\end{array}$ & $\begin{array}{c}\text { Reduce Capital } \\
\text { Gains/Dividends } \\
\text { Tax Rate }\end{array}$ & $\begin{array}{c}\text { Index Social } \\
\text { Security } \\
\text { Thresholds }\end{array}$ & $\begin{array}{c}\text { Eliminate Social } \\
\text { Security } \\
\text { Thresholds }\end{array}$ \\
\hline Total & 100.0 & 100.0 & 100.0 & 100.0 & 100.0 & 100.0 \\
\hline $\begin{array}{l}\text { Sex } \\
\text { Female } \\
\text { Male }\end{array}$ & $\begin{array}{l}53.4 \\
46.6\end{array}$ & $\begin{array}{l}55.5 \\
44.5\end{array}$ & $\begin{array}{l}49.9 \\
50.1\end{array}$ & $\begin{array}{l}55.7 \\
44.3\end{array}$ & $\begin{array}{l}55.0 \\
45.0\end{array}$ & $\begin{array}{l}55.3 \\
44.7\end{array}$ \\
\hline $\begin{array}{l}\text { Marital Status } \\
\text { Married } \\
\text { Widowed } \\
\text { Divorced } \\
\text { Never married }\end{array}$ & $\begin{array}{l}60.7 \\
11.7 \\
15.8 \\
11.9\end{array}$ & $\begin{array}{l}55.4 \\
15.8 \\
15.9 \\
12.9\end{array}$ & $\begin{array}{l}42.6 \\
23.5 \\
21.0 \\
12.8\end{array}$ & $\begin{array}{l}54.2 \\
16.4 \\
16.1 \\
13.3\end{array}$ & $\begin{array}{l}53.5 \\
14.9 \\
17.7 \\
14.0\end{array}$ & $\begin{array}{l}54.4 \\
16.6 \\
16.5 \\
12.5\end{array}$ \\
\hline $\begin{array}{l}\text { Race/Ethnicity } \\
\text { White, non-Hispanic } \\
\text { Black, non-Hispanic } \\
\text { Hispanic } \\
\text { Asian/Native American }\end{array}$ & $\begin{array}{c}67.4 \\
10.3 \\
14.9 \\
7.4\end{array}$ & $\begin{array}{c}73.6 \\
8.5 \\
10.7 \\
7.2\end{array}$ & $\begin{array}{c}83.5 \\
7.8 \\
5.8 \\
3.0\end{array}$ & $\begin{array}{c}87.7 \\
2.9 \\
4.3 \\
5.1\end{array}$ & $\begin{array}{c}70.5 \\
11.4 \\
12.9 \\
5.2\end{array}$ & $\begin{array}{c}72.3 \\
11.7 \\
12.3 \\
3.8\end{array}$ \\
\hline $\begin{array}{l}\text { Education } \\
\text { High school dropout } \\
\text { High school graduate } \\
\text { College graduate }\end{array}$ & $\begin{array}{l}13.1 \\
58.1 \\
28.8\end{array}$ & $\begin{array}{c}6.9 \\
49.8 \\
43.3\end{array}$ & $\begin{array}{c}1.2 \\
28.5 \\
70.3\end{array}$ & $\begin{array}{c}2.3 \\
28.8 \\
68.9\end{array}$ & $\begin{array}{c}7.4 \\
67.6 \\
25.0\end{array}$ & $\begin{array}{c}9.4 \\
66.8 \\
23.7\end{array}$ \\
\hline $\begin{array}{l}\text { Lifetime Earnings } \\
\text { 1st Quintile } \\
\text { 2nd Quintile } \\
\text { 3rd Quintile } \\
\text { 4th Quintile } \\
\text { 5th Quintile }\end{array}$ & $\begin{array}{l}20.0 \\
20.0 \\
20.0 \\
20.0 \\
20.0\end{array}$ & $\begin{array}{c}8.4 \\
11.9 \\
16.5 \\
23.0 \\
40.2\end{array}$ & $\begin{array}{c}0.0 \\
-0.3 \\
1.0 \\
12.3 \\
87.0\end{array}$ & $\begin{array}{c}1.2 \\
2.3 \\
5.2 \\
14.4 \\
77.0\end{array}$ & $\begin{array}{c}9.1 \\
25.2 \\
28.4 \\
25.1 \\
12.2\end{array}$ & $\begin{array}{l}13.5 \\
27.7 \\
28.2 \\
19.7 \\
10.9\end{array}$ \\
\hline $\begin{array}{l}\text { Household Income } \\
\text { 1st Quintile } \\
\text { 2nd Quintile } \\
\text { 3rd Quintile } \\
\text { 4th Quintile } \\
\text { 5th Quintile }\end{array}$ & $\begin{array}{l}20.0 \\
20.0 \\
20.0 \\
20.0 \\
20.0\end{array}$ & $\begin{array}{c}7.7 \\
10.8 \\
15.3 \\
22.9 \\
43.4\end{array}$ & $\begin{array}{c}0.0 \\
-0.2 \\
0.8 \\
3.6 \\
95.8\end{array}$ & $\begin{array}{c}0.4 \\
2.2 \\
5.0 \\
12.5 \\
79.9\end{array}$ & $\begin{array}{c}5.1 \\
25.7 \\
44.6 \\
22.9 \\
1.7\end{array}$ & $\begin{array}{c}10.3 \\
41.4 \\
35.4 \\
11.7 \\
1.2\end{array}$ \\
\hline Unweighted Obs. & 7,958 & 7,958 & 7,958 & 7,958 & 7,958 & 7,958 \\
\hline
\end{tabular}

Notes: Sample includes adults born 1960 to 1964.

Source: Authors' tabulations of DYNASIM3 (see text for details). 


\section{Positive Returns}

Financial Assets ( $t 1$ )

Retirement Account $(t 1)$

Total Wealth $(t 1)$

Financial Asset Return

Retirement Account Return

Tax Rate

Financial Asset After-tax Return

Financial Assets ( $t 2$ )

Retirement Account ( $t 2)$

Total Wealth (t2)

Gain (loss) from Baseline

Negative Returns

Financial Assets ( $t 1$ )

Retirement Account ( $t 1$ )

Total Wealth ( $t 1)$

Financial Asset Return

Retirement Account Return

Tax Rate

Financial Asset After-tax Return

Financial Assets ( $t 2$ )

Retirement Account ( $t 2$ )

Total Wealth (t2)

Gain (loss) from Baseline

\begin{tabular}{|c|c|c|}
\hline Baseline & $\begin{array}{c}\text { Extra Saving } \\
\text { in Retirement } \\
\text { Account }\end{array}$ & $\begin{array}{c}\text { Extra Saving in } \\
\text { Financial } \\
\text { Assets }\end{array}$ \\
\hline$\$ 10,000$ & $\$ 9,500$ & $\$ 10,500$ \\
\hline$\$ 10,000$ & $\$ 10,500$ & $\$ 9,500$ \\
\hline$\$ 20,000$ & $\$ 20,000$ & $\$ 20,000$ \\
\hline$\$ 500$ & $\$ 475$ & $\$ 525$ \\
\hline$\$ 500$ & $\$ 525$ & $\$ 475$ \\
\hline$\$ 0$ & $\$ 0$ & $\$ 0$ \\
\hline$\$ 425$ & $\$ 404$ & $\$ 446$ \\
\hline$\$ 10,425$ & $\$ 9,904$ & $\$ 10,946$ \\
\hline$\$ 10,500$ & $\$ 11,025$ & $\$ 9,975$ \\
\hline$\$ 20,925$ & $\begin{array}{c}\$ 20,929 \\
\$ 4\end{array}$ & $\begin{array}{c}\$ 20,921 \\
(\$ 4)\end{array}$ \\
\hline$\$ 10,000$ & $\$ 9,500$ & $\$ 10,500$ \\
\hline$\$ 10,000$ & $\$ 10,500$ & $\$ 9,500$ \\
\hline$\$ 20,000$ & $\$ 20,000$ & $\$ 20,000$ \\
\hline$-\$ 500$ & $-\$ 475$ & $-\$ 525$ \\
\hline$-\$ 500$ & $-\$ 525$ & $-\$ 475$ \\
\hline$\$ 0$ & $\$ 0$ & $\$ 0$ \\
\hline$-\$ 425$ & $-\$ 404$ & $-\$ 446$ \\
\hline$\$ 9,575$ & $\$ 9,096$ & $\$ 10,054$ \\
\hline$\$ 9,500$ & $\$ 9,975$ & $\$ 9,025$ \\
\hline$\$ 19,075$ & $\begin{array}{c}\$ 19,071 \\
(\$ 4)\end{array}$ & $\begin{array}{c}\$ 19,079 \\
\$ 4 \\
\end{array}$ \\
\hline
\end{tabular}

Source: Authors' calculations. 


\section{RECENT WORKING PAPERS FROM THE}

\section{CENTER FOR RETIREMENT RESEARCH AT BOSTON COLLEGE}

Saving and Wealth Accumulation in the PSID, 1984-2005

Barry P. Bosworth and Sarah Anders, February 2008

Older Women's Income and Wealth Packages in Cross-National Perspective

Timothy M. Smeeding, Janet C. Gornick, Eva Sierminska, and Maurice Leach, February 2008

How Many Struggle to Get By in Retirement?

Barbara A. Butrica, Daniel Murphy, and Sheila R. Zedlewski, January 2008

The Impact of Late-Career Health and Employment Shocks on Social Security and Other Wealth

Richard W. Johnson, Gordon B.T. Mermin, and Dan Murphy, December 2007

The Effect of Economic Conditions on the Employment of Workers Nearing Retirement Age

Till von Wachter, December 2007

The Costs of Owning Employer Stocks: Lessons From Taiwan

Yi-Tsung Lee, Yu-Jane Liu, and Ning Zhu, December 2007

Health Insurance and the Labor Supply Decisions of Older Workers: Evidence from the U.S. Department of Veterans Affairs

Melissa A. Boyle and Joanna N. Lahey, December 2007

Why Are Companies Freezing Their Pensions?

Alicia H. Munnell and Mauricio Soto, December 2007

Capital Income Flows and the Relative Well-Being of America's Aged Population Barry P. Bosworth, Gary Burtless, and Sarah E. Anders, December 2007

The Role of Governance in Retirement Investments: Evidence from Variable Annuities

Richard Evans and Rudiger Fahlenbrach, October 2007

\section{A New Approach to Raising Social Security's Earliest Eligibility Age}

Kelly Haverstick, Margarita Sapozhnikov, Robert Triest, and Natalia Zhivan, October 2007

All working papers are available on the Center for Retirement Research website

(http://www.bc.edu/crr) and can be requested by e-mail (crr@bc.edu) or phone (617-552-1762). 